University of Wollongong

Research Online

Faculty of Engineering and Information

Faculty of Engineering and Information

Sciences - Papers: Part B

Sciences

2018

Mechanical response and pore pressure generation in granular filters subjected to uniaxial cyclic loading

Jahanzaib Israr

University of Wollongong, jisrar@uow.edu.au

Buddhima Indraratna

University of Wollongong, indra@uow.edu.au

Follow this and additional works at: https://ro.uow.edu.au/eispapers1

Part of the Engineering Commons, and the Science and Technology Studies Commons

Research Online is the open access institutional repository for the University of Wollongong. For further information contact the UOW Library: research-pubs@uow.edu.au 


\title{
Mechanical response and pore pressure generation in granular filters subjected to uniaxial cyclic loading
}

\author{
Abstract \\ This paper presents results from a series of piping tests carried out on a selected range of granular filters \\ under static and cyclic loading conditions. The mechanical response of filters subjected to cyclic loading \\ could be characterized in three distinct phases; namely, (I) pre-shakedown, (II) post-shakedown, and (III) \\ post-critical (i.e., the occurrence of internal erosion). All the permanent geomechanical changes such, as \\ erosion, permeability variations, and axial strain developments, took place during phases I and III, while \\ the specimen response remained purely elastic during phase II. The post-critical occurrence of erosion \\ incurred significant settlement that may not be tolerable for high-speed railway substructures. The \\ analysis revealed that a cyclic load would induce excess pore-water pressure, which, in corroboration with \\ steady seepage forces and agitation due to dynamic loading, could then cause internal erosion of fines \\ from the specimens. The resulting excess pore pressure is a direct function of the axial strain due to \\ cyclic densification, as well as the loading frequency and reduction in permeability. A model based on \\ strain energy is proposed to quantify the excess pore-water pressure, and subsequently validated using \\ current and existing test results from published studies.

\section{Disciplines} \\ Engineering | Science and Technology Studies

\section{Publication Details} \\ Israr, J. \& Indraratna, B. (2018). Mechanical response and pore pressure generation in granular filters \\ subjected to uniaxial cyclic loading. Canadian Geotechnical Journal, 55 (12), 1756-1768.
}




\section{Granular Filters subjected to Uniaxial Cyclic Loading}

3 Jahanzaib Israr, BSc (Pak), MSc (Lhr.), PhD (Wollongong)

4 Associate Research Fellow, Centre for Geomechanics and Railway Engineering (GRE), Faculty

5 of Engineering, Univ. of Wollongong, Wollongong City, NSW 2522, Australia. Assistant

6 Professor of Civil Engineering, Univ. of Engineering and Technology Lahore, Pakistan (On

7 study leave). E-mail: jisrar@uow.edu.au

9 Buddhima Indraratna, BSc (Eng), MSc (Lond.), DIC, PhD (Alberta), FIEAust., FASCE

10 Distinguished Professor of Civil Engineering, Founding Director of Centre for Geomechanics 11 and Railway Engineering (GRE), Faculty of Engineering, Faculty of Engineering, Univ. of

12 Wollongong, Wollongong City, NSW 2522, Australia. E-mail: indra@uow.edu.au

13 Date of Submission: 06 November 2017

14 Submitted to: Canadian Geotechnical Journal

15

16 Author for correspondence:

17 Dr. J. Israr

18 Faculty of Engineering

19 University of Wollongong

20 Wollongong, NSW 2522

21 Australia.

22 Ph: +61242213046

23 Fax: +61242213238

24 Email: jisrar@uow.edu.au 


\section{Granular Filters subjected to Uniaxial Cyclic Loading}

Jahanzaib Israr, Ph.D ${ }^{1}$ and Buddhima Indraratna, Ph.D., F.ASCE ${ }^{2}$

\section{Abstract:}

This paper presents the results from a series of piping tests carried out on a selected range of granular filters under static and cyclic loading conditions. The mechanical response of filters subjected to cyclic loading could be characterised in 3 distinct phases; namely (i) preshakedown, (II) post-shakedown, and (III) post-critical (i.e. the occurrence of internal erosion). All the permanent geomechanical changes such as erosion, permeability variations and axial strain developments took place during phases I and III, while the specimen response remained purely elastic during phase II. The post-critical occurrence of erosion incurred significant settlement that may not be tolerable for high-speed railway substructures. The analysis revealed that a cyclic load would induce excess pore water pressure, which, in corroboration with steady seepage forces and agitation due to dynamic loading could then cause internal erosion of fines from the specimens. The resulting excess pore pressure is a direct function of the axial strain due to cyclic densification, as well as the loading frequency and reduction in permeability. A model based on strain energy is proposed to quantify the excess pore water pressure, and subsequently validated using current and existing test results from published studies.

Author keywords: Granular filters, Pore pressure, Internal erosion, Cyclic load, Frequency

${ }^{1}$ Associate Research Fellow, Centre for Geomechanics and Railway Engineering (GRE), Faculty of Engineering, Univ. of Wollongong, Wollongong City, NSW 2522, Australia. Assistant Professor of Civil Engineering, Univ. of Engineering and Technology Lahore, Pakistan. (corresponding author). E-mail: jisrar@uow.edu.au. 


\section{Introduction}

2 Granular filters protect base soils such as dam cores and natural erodible subgrades from

3 erosion, while alleviating potential build-up of excess pore water pressure. Recent advances in

4 geotechnical practices have generated an interest in applying these granular filters to

5 geohydraulic and transportation infrastructure facilities (Sansalone et al. 2008; Koerner et al.

6 1994; Fourie et al. 1994), where filtration occurs under adverse loading conditions (i.e. both

7 static and cyclic loading). Unlike large upstream seepage heads in dams, hydraulic excitation

8 in railway sub-structures stems mainly from the generation of pore water pressure in natural

9 subgrades and engineered fills, e.g. subballast (Indraratna et al. 2017; Selig and Waters 1994).

10 Previous studies revealed that the filters within these structures would be under complex

11 dynamic stress states and thus have a significant influence on the erosion of fine particles such

12 as base-soil migration, suffusion, and internal erosion (Indraratna et al. 2017; Chang and Zhang

13 2013; Xiao and Shwiyhat 2012; Trani and Indraratna 2010; Burenkova 1993). Nonetheless,

14 limited migration of base fines into filters may occasionally establish self-filtering layers that

15 help prevent any further erosion and increase their internal stability. However, strong upward

16 seepage may develop significant structural instabilities such as piping, segregation erosion and

17 heave, and associated deterioration in permeability as base soil erodes into the overlying filter

18 layers may initiate progressive clogging, especially under cyclic loading conditions (Trani and

19 Indraratna 2010).

20 The loading conditions in railway substructures are cyclic, unlike the steady seepage under

21 static loading that usually occurs in dams and levees. A subballast filter performs two major

22 functions in track environments; namely (a) cope with the sustainable transfer of stress from

23 the ballast to the subgrade, and (b) protect subgrade fines from upward pumping due to seepage

24 and the build-up of pore pressure due to cyclic loading. An effective subballast filter mitigates

25 ballast fouling from the substructure and reduces the risk of track settlement and related 
1 instability due to clay pumping (Selig and Waters 1994). However, inadequately designed

2 subballast subjected to excessive pore pressure and agitation induced by cyclic loading could

3 lose its own finer fractions to internal erosion, and thereby experience changes in its particle

4 gradation (i.e. internal instability) which may result in a highly porous and ineffective filter 5 layer.

6 As Figure 1 shows, cyclic loading induces significant magnitude of pore water pressure $(\Delta u)$,

7 which may be classified into two components, namely: residual and transient (Sassa and

8 Sekiguchi 1999). Given that the mean of transient $\Delta u$ is usually zero, it does not accumulate

9 and thus causes no significant reductions in the effective stresses of soils. However, the residual

10 component of $\Delta u$ may accumulate over time at higher loading frequencies, depending on the

11 soil properties, the volumetric strain rate, drainage conditions, and the number of loading cycles

12 (Trani and Indraratna 2010; Polito et al. 2008). A large increase in the accumulated residual

$13 \Delta u$ may disturb the constriction size distribution (CSD) network quite considerably and reduce

14 the effective stress in soils (Indraratna et al. 2017; Xiao et al. 2006). The possible results of this

$15 \Delta u$ generation may include but not be limited to excessive internal erosion, premature suffusion

16 and piping in the drainage layer, as well as fluidization of soft saturated natural subgrades, thus

17 causing the substructure to experience severe mud-pumping and excessive ballast fouling from

18 the substructure (Indraratna et al. 2012; Selig and Waters 1994).

19 Thus far, various researchers have attempted to model the generation of pore pressure in 20 granular soils to quantify their potential for liquefaction during earthquakes. The existing 21 models of pore pressure generation are either (a) stress based, or (b) energy based. The former 22 are generally built empirically based on laboratory and field observations which have been 23 continually refined through novel studies and classical case histories (e.g. Seed and Idris 1971;

24 Youd et al. 2001). In contrast, the energy based models use relationships between various forms 25 of energy released during seismic activities and the corresponding pore water pressure (e.g. 
1 Gutenberg and Richter 1942; Nemat-Nasser and Shokooh 1979). Given that the period and

2 number of cycles of high-speed train loading are generally greater than the dynamic load during

3 a typical earthquake, the likelihood of significant pore pressure developing in railway

4 substructures can be very high. The authors realise that there is no specific and elaborate

5 literature on the generation of pore pressure in railway substructures, so this current study

6 purports to improve our understanding of this phenomenon and attempts to model the

7 development of pore water pressure in subballast filters subjected to high-speed cyclic loading.

8 In this regard, a series of hydraulic tests under static and cyclic loading conditions was carried

9 out on a selected range of compacted granular soils. An analysis of the static and cyclic tests is

10 presented and a semi-empirical energy based approach is proposed herein to capture the

11 generation of pore pressure in granular filters subjected to cyclic train loading.

12 In this study, a total of 32 hydraulic tests have been carried out in two different phases. In first

13 phase, 16 hydraulic tests were conducted under static loading with a twofold objective; namely

14 (1) to examine the effects of overburden confinement to simulate stationary train conditions on

15 the mechanical and drainage characteristics of subballast filters, and (2) to use as a benchmark

16 dataset to compare with the results of non-standard filtration tests under cyclic loading. During

17 phase-2, another 16 tests were conducted under uniaxial cyclic loading to capture the hydraulic

18 response of subballast filters under simulated dynamic train loading on Australian standard

19 gauge tracks. During static and cyclic tests, the monitored parameters and soil characteristics

20 included time-dependent variations in permeability, internal erosion and axial strain

21 development, pore pressure measurements, and average and local hydraulic gradients

22 contributing to geohydraulic failures such as suffusion, piping and heave. While the parameters

23 compared from static and cyclic loading tests included average and local hydraulic gradients

24 and associated head losses, permeability variations, pre- and post-test relative densities, types

25 of seepage failures, and percentile internal erosion. 


\section{Experimental Program}

\section{Testing Material and Scheme}

3 The test material consists of 4 non-uniform granular soils including 3 sand-gravel and 1 silt-

4 sand-gravel mixtures (uniformity coefficient $C_{u}=10,20,23$, and 304) which are identified as

5 S, MS, MU, and U, respectively (Fig.2). The current soils are symbolised based on their

6 potential of internal erosion determined by the criterion proposed earlier by Indraratna et al.

7 (2015), where S, MS, MU and U represent Stable, Marginally Stable, Marginally Unstable and

8 Unstable soils, respectively. For brevity, this criterion compares the representative particle size

9 of finer fraction of soil at $85^{\text {th }}$ percentile finer by surface area $\left(d_{85, A S}^{f}\right)$ against the controlling

10 constriction size of its coarser fraction $\left(d_{c 35}^{c}\right)$, and this would enable one to determine if a given

11 soil would be susceptible to internal erosion under excessive seepage. These soil gradations

12 typically represent the subballast filters to protect erodible subgrades from contaminating the

13 ballast under cyclic loading in railway foundations in New South Wales (NSW) (e.g. Selig and

14 Waters 1994; Haque et al. 2007; Trani and Indraratna 2010; Chung et al. 2012). During the

15 static tests, the normal effective stress $\left(\sigma_{v}^{\prime}\right)$ varied from 0 to $100 \mathrm{kPa}$, while a sinusoidal load

$16\left(\sigma_{\min }^{\prime}=30, \sigma_{\max }^{\prime}=70, \sigma_{d e v}^{\prime}=40\right.$ and $\left.\sigma_{\text {mean }}^{\prime}=50 \mathrm{kPa}\right)$ was applied to simulate typical

17 heavy haul train movements during the cyclic tests. Cyclic loading frequencies of 5, 10, 20 and

$1830 \mathrm{~Hz}$ were applied to simulate speeds up to $210 \mathrm{~km} / \mathrm{hr}$ on standard gauge tracks (Christie

19 2007; Trani and Indraratna 2010; Israr et al. 2016). Notably, cyclic loading was applied from

20 top and hydraulic flow from bottom of test specimens simultaneously, as now shown in Figure

21 4. Both cyclic and static loads were applied using the same automated hydraulic actuator, which

22 could apply cyclic stresses at frequencies $(f)$ up to $40 \mathrm{~Hz}$ and normal static stresses up to 850

$23 \mathrm{kPa}$. For instance, static loading could be simulated using the same actuator by setting cyclic

24 frequency to zero $(f=0 \mathrm{~Hz})$. 
1 In this study, each test sample was identified by a three-character acronym, where the first

2 character describes the type of soil such as S, MS, MU, and U, the second character shows the

3 test condition, i.e. $\mathrm{S}$ for static and $\mathrm{C}$ for cyclic, and the third character represents the magnitude

4 of the static load or cyclic frequency. For instance, specimens U-S100 and U-C30 represent

5 soil $\mathrm{U}$ subjected to static normal stress ${\sigma^{\prime}}_{v t}=100 \mathrm{kPa}$ and cyclic frequency $f=30 \mathrm{~Hz}$,

6 respectively.

\section{$7 \quad$ Sampling and Apparatus}

8 Test specimens were prepared at a relative density of $\left(R_{d}\right) \geq 95 \%$ by controlling the mass of

9 dry soil to achieve the minimum void ratio $\left(e_{\min }\right)$, previously obtained from preliminary

10 compaction tests (ASTM D4253). For instance, the specimens were compacted in 5 discrete

11 layers under a $10 \mathrm{~kg}$ surcharge load on a vibrating table (frequency, $f=50 \mathrm{~Hz}$ ) to achieve the

12 target sample height (after Trani and Indraratna 2010; Israr et al. 2016). To ensure the specimens are compacted uniformly, additional specimens were prepared and examined for; (i) their overall dry density, and (ii) the dry density of small samples cored within each specimen (Indraratna et al. 2015). Similarly, specimen uniformity with respect to particle distribution was ensured by comparing the results of pre- and post-test sieve analyses.

As Fig. 2 shows, the testing apparatus consists of a low-friction polycarbon hydraulic cell (diameter $D_{C}=240 \mathrm{~mm}$ and height $H_{C}=250 \mathrm{~mm}$ ) to accommodate $200 \mathrm{~mm}$ long samples. These dimensions of this cell are large enough to yield a ratio $\mathrm{R}=D_{C} / d_{100}>12$, where $d_{100}=$ particle size which corresponds to $100 \%$ finer by mass. In the past, most hydraulic tests were carried out with apparatuses yielding $4 \leq \mathrm{R} \leq 7$ (e.g. Moffat and Fannin 2011; Zou et al. 2013; Indraratna et al. 2015; Israr 2016), because this range would be sufficient to avoid most of the potential boundary effects due to soil erosion. 
1 Two $50 \mathrm{~mm}$ diameter pressure cells were placed in the middle and the bottom of the specimens

2 to monitor seepage induced variations in the confining stress. The authors carefully examined

3 the inclusion of pressure cells given that their presence may significantly modify the assumed

$4 \quad 1 \mathrm{D}$ geometry of the seepage problem and cause local heterogeneities such as non-vertical

5 seepage flow and porosity deteriorations, as these could trigger premature geo-hydraulic

6 failures in the specimens (Moffat and Fannin 2011). For completeness, a total of six

7 independent seepage tests were conducted, i.e. 3 with and 3 without pressure cells, which

8 constitute approximately $2.2 \%$ of the total soil volume in a specimen compared to the collective

9 volume of other accessories (e.g. ADR probes, wires, and transducers $\approx 0.4 \%$ ), as explained

10 elsewhere by Israr et al. (2016). The analysis of results revealed that the porosity variations

11 before the initiation of seepage failures were uniform and independent of the presence of

12 pressure cells. For instance, specimens with and without pressure cells showed similar

13 hydraulic responses, thus for a given soil specimen the failure initiated in the same soil layer

14 and at a unique combination of hydraulic gradient and effective stress. This sufficiently

15 confirmed that the presence of pressure cells had negligible effects on the reported test results

16 of this study.

\section{Saturation and Test Procedure}

18 To avoid any potential disturbances saturation was completed by following the procedure of

19 Israr et al. (2016). For brevity, the specimens were first de-aired by applying up to $120 \mathrm{kPa}$ of back pressure for 2 to 3 hours, and then the de-aired and filtered water was circulated. The test samples were saturated for at least 24 hours under a constant hydraulic head of $50 \mathrm{~mm}$. Notably, complete saturation of a test specimen could be ensured to a satisfactory extent by achieving Skempton's B value $>0.90$; and this was completed in 3 to 4 pressure ramps with a very low pressure difference of $10 \mathrm{kPa}$ between the cell and the applied back pressures (after Amini and Hamidi 2014). 
1 An upwards seepage flow was introduced from the bottom of the test chamber at predetermined

2 pressures using an automated hydraulic pump. The variations in hydraulic pressure and

3 associated average and local head losses were monitored with 8 pore water pressure transducers

4 embedded at the inlet, the outlet, and at six different depths inside each sample. The average

5 hydraulic gradient $\left(i_{a}\right)$ is then deduced from the difference between the inflow $\left(p_{w}^{i n}\right)$ and

6 outflow pressures $\left(p_{w}^{\text {out }}\right)$ :

$7 \quad i_{a}=\left(p_{w}^{\text {in }}-p_{w}^{\text {out }}\right) /\left(h_{f} \times \gamma_{w}\right)$

where $h_{f}$ and $\gamma_{w}$ define the thickness of the sample and the unit weight of water, respectively.

9 The local hydraulic gradients $\left(i_{i j}\right)$ which evolve as the internal porosity deteriorates is deduced

10 from the differences in head loss, which occurs across discrete layers of soil $(\Delta y)$ :

$11 \quad i_{i j}=\left(p_{w}^{j}-p_{w}^{i}\right) /\left(\Delta y \times \gamma_{w}\right)$

12 where $p_{w}^{i}$ and $p_{w}^{j}$ are the hydraulic pressures in $\mathrm{i}^{\text {th }}$ and $j^{\text {th }}$ soil layers, respectively. The 13 difference in elevation (potential head) for Eq. 1a is $200 \mathrm{~mm}$, whilst that for Eq. $1 \mathrm{~b}$ is $25 \mathrm{~mm}$ near the boundaries, and $30 \mathrm{~mm}$ in the middle of the test specimen.

The test procedure consisted of applying an upward hydraulic flow at pre-requisite pressure levels. The increments of hydraulic gradient $\left(i_{a}\right)$ for the stable sample-S were kept between 3 and 4, for the marginal samples MS and MU between 2 and 3, and for the unstable sample U between 1 and 2. These increments proved adequate to avoid disturbance to the specimens unnecessarily and helped to determine the correct critical hydraulic gradients $i_{c r, \exp }$ (Fig. 3). Each test continued for a minimum of 30-40 minutes at a given $i$-value, beyond which steady state flow conditions were generally reached and then the next increment in $i$ applied. Not surprisingly, an average test lasted up to 13.5 hours, i.e. some tests ran up to 11 hours (e.g. US0 and U-C5) and others up to 16 hours (e.g. U-S100, U-C30, S-C30 and MU-C30). The velocity and turbidity of the effluent were monitored repeatedly during each test by intercepting 
1 the flow over a given period of time. By assuming linear Darcy's law, the saturated hydraulic

2 conductivity was deduced from the slope of the flow curves in Figs. 3a and 3b. The turbidity

3 of the effluent was monitored using Nephelometric Turbidity Unit (NTU) via a portable

4 turbidimeter, while a large, $1 \mathrm{~m}^{3}$ sedimentation tank was used to capture the eroded fines for

5 post-test forensic analysis. In this study, the hydraulic tests were continued until at least one of

6 the following observations could be made; referred to as geohydraulic failure (Israr and

7 Indraratna 2017; Israr et al. 2016; Indraratna et al. 2015):

8 (i)- A significant variation in the slope of the flow curves plotted as an applied hydraulic 9 gradient $i_{a}$ versus effluent flow rate $Q_{e}$ in litre/min. At the onset of slope variation, the 10 corresponding value of $i_{a}$ is assumed as the average critical hydraulic gradient $i_{c r, a}$ (Eq. 1),

11 (ii)- A sudden drop in the magnitude of a local hydraulic gradient $i_{i j}$, i.e. the local critical 12 hydraulic gradient $i_{c r, i j}$ (Eq. 2),

13 (iii)- Excessive washout and a marked rise in effluent turbidity ( $\gg 60 \mathrm{NTU}$ ), and

14 (iv)- The development of visible vertical or horizontal channels, which could be identified 15 as heave.

16 The tested specimens were retrieved in three distinct layers, i.e. top, middle, and bottom, for 17 post-test sieve analysis to determine the extent of internal erosion and any changes in their original particle size distribution (PSD) curves. Notably, internal erosion in the test specimens could be partially represented by the loss of fine particles that may alter their PSD curves; for 20 instance, samples U-S100 and U-C30 experienced $8.9 \%$ and $15.7 \%$ internal erosion at the 21 particle size $d_{10}$-level and showed dramatic reductions in the coefficient of uniformity from 304 to 43 and 35, respectively. Nevertheless, changes in the original PSD of the middle layer, or more than $4 \%$ of internal erosion, were then considered as rationales to distinguish between internally stable and unstable soils (after Israr et al. 2016; Indraratna et al. 2017; Kenney and 
1 Lau 1985). The geometrical assessments revealed that under static conditions, only soil U was

2 internally unstable (Indraratna et al. 2015), whereas the only existing criterion for cyclic

3 conditions indicated that soils MS, MU, and U were internally unstable (Israr and Indraratna

4 2017). Nonetheless, the following section evaluates the seepage-induced response

5 experimentally and then re-examines the internal erosion potential of all four soils under both

6 static and cyclic conditions.

\section{$7 \quad$ Results and Discussion}

8 Table 1 summarises the hydraulic test results of this current study including the test conditions

9 (static or cyclic), the pre- and post-test relative density $\left(R_{d}\right)$, the average critical hydraulic 10 gradient $\left(i_{c r, a}\right)$, local critical hydraulic gradients $\left(i_{c r, i j}\right)$, additional hydraulic gradient induced 11 by the pore water pressure $\left(i_{\Delta u}\right)$, and the percentage of internal erosion and type of seepage 12 induced failure (i.e. heave, heave-piping or suffusion). The following sections elaborate on the 13 specific details of the hydraulic test results.

\section{Hydraulic Response under Static and Cyclic Loading}

15 Figure 3 shows the results of hydraulic tests on fully compacted soil $\mathrm{U}\left(R_{d} \geq 95 \%\right)$, subjected to static loading magnitudes of $0,25,50$ and $100 \mathrm{kPa}$ (Table 1). As Fig. 3a shows, the flow curves plotted as average hydraulic gradient $i_{a}$ versus effluent flow rate $Q_{e}$ developed steadily with the increasing magnitude of static loading. The saturated permeability of the soil samples was deduced from the slope of the initial portion of the flow curves by assuming linear Darcy's law. A comparison of the pre- and post-test results reveals that the saturated permeability of soils remains independent of the magnitude of static loading (Table 1). Notably, the flow rate does not vary significantly for very small lengths of flow curves within the laminar regime e.g. e.g. up to $i_{a} \leq 0.1$ and $Q_{e} \leq 0.04 \mathrm{lit} / \mathrm{min}$ for the specimen $\mathrm{U}$, as now shown in Fig. 3a (inset), where the slopes of flow curves remained relatively unchanged. However, we know that the 
1 slopes would decrease markedly due to higher hydraulic head losses at particle contact levels

2 under larger effective stress magnitudes until the occurrence of suffusion (Langroudi et al.

3 2013; Zou et al. 2013; Qing-fu et al. 2014). So this flow rate is not just a function of sample

4 dimensions and specimen permeability, but also influenced by the external hydraulic loads.

5 Notably, this is consistent with the previous studies which report that the suffusion potential

6 decreases with the increase in static loading magnitude (e.g. Li and Fannin 2008; Moffat and

$7 \quad$ Fannin 2011; Moffat and Herrera 2014; Israr et al. 2016).

8 The inception or onset of suffusion in soil $U$ is characterised by a steep increase in the rate of 9 effluent flow with turbidity in excess of $60 \mathrm{NTU}$, and a marked variation in the shape of the 10 flow curve (Fig. 3a). Notably, the magnitude of average critical hydraulic gradient $i_{c r, a}$ for 11 suffusion increased proportionally from 0.26 to 25.5 with the magnitude of static load 12 increasing from 0 to $100 \mathrm{kPa}$. Figure $3 \mathrm{~b}$ shows the time histories of axial strain for soil $\mathrm{U}$, with no significant compression prior to suffusion, although limited internal erosion continues at all $i_{a}$-values. The shapes of the strain curves remain identical before suffusion (i.e. excessive erosion of fines), which increases the void ratio and allows particles to rearrange and compress 16 further, as shown by the sudden increase in the axial strain values (Fig. 3b). Nevertheless, the 17 time for suffusion to commence in soil $\mathrm{U}$ increased when the static loading increased from 0 to $100 \mathrm{kPa}$; this shows the stabilising effects of static loading.

19 Figure 4 shows the flow curves and axial strain histories for compacted soil $\mathrm{U}\left(R_{d} \geq 95 \%\right)$, subjected to cyclic loading at frequencies of 5, 10, 20, and $30 \mathrm{~Hz}$. Unlike under static loading,

21 the magnitudes of $i_{c r, a}$ for soil $\mathrm{U}$ decreases from 29.4 to 24.7 when the cyclic frequency 22 increases from 5 to $30 \mathrm{~Hz}$. The cyclic loading conditions reduce the pre-test permeability of 23 soil $\mathrm{U}$ in proportion to the cyclic loading frequency (Table 1). Not surprisingly, the axial strain 24 histories under cyclic loading show significant initial compression before reaching an almost 
1 constant strain condition termed as elastic shakedown, until suffusion commences. During the

2 elastic shakedown, the specimen response remains generally rigid with almost no variations in

3 the strain rates that can be attributed to particle rearrangements and some limited erosion.

4 Nevertheless, the time for elastic shakedown to occur appears to be frequency dependent, e.g.

$5360 \mathrm{~min}$ for sample U-C5 (i.e. at $5 \mathrm{~Hz}$ ) compared to $110 \mathrm{~min}$ for sample U-C30 (at $30 \mathrm{~Hz}$ ).

6 As Figures 5a and 5b show, the time for elastic shakedown to commence in samples $\mathrm{S}$ and MS

7 decreases markedly when the loading frequency increases from 5 to $30 \mathrm{~Hz}$. Notably, up to $95 \%$

8 strain energy has accumulated at the elastic shakedown and this has had a significant influence

9 on the development of excess pore water pressure (Polito et al. 2008; Seed et al. 1983), and

10 then the inception of geohydraulic failure (Israr et al. 2016). Nevertheless, the strain rate

11 beyond elastic shakedown remains negligible until and after the onset of heave in samples $\mathrm{S}$,

12 where variations in strain evolve due to particle rearrangements. However, no significant axial

13 strain develops, even after the inception of heave, due to negligible erosion of finer fractions

14 from the internally stable samples S. However, there appears to be a marked increase in axial

15 strain after the inception of suffusion due to the significant erosion of finer fractions from an

16 internally unstable sample U.

17 An analysis of the time histories of local hydraulic gradients $\left(i_{i j}\right)$ for sample $\mathrm{U}$ subjected to 18 static and cyclic loading is shown in Figs. 6a and 6b, respectively. During a static test U-S50

19 (under a static normal stress of $50 \mathrm{kPa}$ ), suffusion initiated in soil layer-56, i.e. at $55 \mathrm{~mm}$ to 85 $\mathrm{mm}$ from the top at a local hydraulic gradient is $i_{c r, i j}=21.9$, whereas during a cyclic test $\mathrm{U}$ -

$21 \mathrm{C} 5$ (at $5 \mathrm{~Hz}$ and mean normal stress of $50 \mathrm{kPa}$ ), suffusion occurred in the same soil layer-56

22 but at a greater value of $i_{c r, i j}=34.5$. This discrepancy in critical hydraulic gradients could be explained by the development of excess pore water pressure due to cyclic loading that induced 
1 a greater $i_{i j}$ at the particle level which, in corroboration with the externally applied hydraulic

2 gradients $i_{a}$, triggered suffusion.

3 Figures $7 \mathrm{a}$ and $7 \mathrm{~b}$ show the effects of cyclic frequency and normal effective stress on the 4 magnitudes of critical hydraulic gradients, respectively. Fig. 7a shows that as the $i_{c r, a}$-values

5 decrease, the $i_{c r, i j}$-values generally increase with the increase in loading frequency, which

6 indicates that the pore water pressure that develops under cyclic loading becomes excessive at 7 a higher loading frequency. The decreasing $i_{c r, a^{-v a l u e s}}$ and increasing $i_{c r, i j}$-values indicate

8 that less external hydraulic pressure is required, while greater internal hydraulic pressure is

9 developed at higher cyclic loading frequencies, thus causing premature geohydraulic failures 10 such suffusion, piping and heave (Israr et al. 2016). Not surprisingly, the values of $i_{c r, a}$ and

$11 i_{c r, i j}$ increase with the increase in static loading from 0 to $100 \mathrm{kPa}$, thus showing the stabilising 12 effects of static loading. For instance, soil under a static load of $25 \mathrm{kPa}$ would require much 13 less $i_{c r, a}$ and $i_{c r, i j}$ for geohydraulic failures to commence, compared to that under $100 \mathrm{kPa}$, 14 thus showing greater internal stability at $100 \mathrm{kPa}$ (see Table 1).

\section{Effects of Pore Pressure Generation under Cyclic Loading}

16 In this study, the magnitude of pore water pressure generated during hydraulic tests under 17 cyclic loading was deduced using the method of Israr et al. (2016). For brevity, the external 18 head loss across the whole sample ( $h_{w}^{t}$ ) could be given by (Eq. 2):

$19 h_{w}^{t}=\frac{p_{w}^{\text {in }}-p_{w}^{\text {out }}}{\gamma_{w}}$

20 where $h_{w}^{\text {in }}$ and $h_{w}^{\text {out }}$ represent the external inflow and outflow hydraulic heads applied to the 21 soil specimens. Similarly, the sum of local head losses $\left(H_{w}^{t}\right)$ was computed using the following expression (Eq. 3): 
$1 \quad H_{w}^{t}=\sum_{i=n}^{j=n+1} \frac{p_{w}^{j}-p_{w}^{i}}{\gamma_{w}}$

2 where $h_{w}^{i}$ and $h_{w}^{i+1}$ represent the local inflow and outflow seepage heads for a discrete soil

3 layer inside a specimen.

4 Now, the equivalent hydraulic head due to induced pore water pressure can be computed as the

5 difference between the overall internal head loss $H_{w}^{t}$ and external head loss $h_{w}^{t}$, as follows:

$6 \quad \Delta u=\left(H_{w}^{t}-h_{w}^{t}\right) \times \gamma_{w}$

7 Not surprisingly, this difference is negligible for the static tests, unlike in the case of cyclic

8 tests where significant differences are recorded (Table 1). The additional pore pressure gradient

$9 \quad\left(i_{\Delta u}\right)$ due to the generation of pore water pressure under cyclic loading was given the following

10 dimensionless expression:

$11 i_{\Delta u}=\Delta u / \gamma_{w} \times \Delta y$

12 where $\Delta y$ is the depth of the soil layer, as shown in Fig. 8. Table 1 summarises the $i_{\Delta u}$-values

13 for current test specimens, where MU and U exhibit manifolds higher $i_{\Delta u}$-values compared to

$14 \mathrm{~S}$ and MS. For instance, under cyclic frequency of $5 \mathrm{~Hz}$, samples S, MS, MU, and U exhibited

$15 i_{\Delta u}=5.9,3.1,10.5$ and 12.5, respectively. Moreover, the magnitude of $i_{\Delta u}$ increased steadily

16 with that of cyclic frequency, e.g. at $30 \mathrm{~Hz}$ frequency, $\mathrm{S}, \mathrm{MS}, \mathrm{MU}$ and $\mathrm{U}$ exhibited $i_{\Delta u}=$

$17 \quad 7.7,4.3,14.9$ and 15.7 , respectively.

18 In practice, the accumulated excess pore water pressure is often quantified in terms of 19 normalized pore pressure ratio $n_{\Delta u}$, which is defined as the ratio of the residual excess pore 20 pressure $\Delta u$ to the initial effective confining stress $\sigma^{\prime}{ }_{c o}$ (Polito et al. 2008). The value of $21 n_{\Delta u}$ varies between zero (i.e., no excess pore pressures) and one (i.e., zero effective stress or

22 fluidization), thus providing more insight than the magnitude of $\Delta u$ alone. 
$1 \quad n_{\Delta u}=\frac{\Delta u}{\sigma_{c o}^{\prime}}$

2 where $n_{\Delta u}$ is the normalised pore pressure ratio, $\sigma^{\prime}{ }_{c o}\left(=\sigma^{\prime}{ }_{m v} \times\left(1+2 K_{0}\right) / 3\right)$ is the mean

3 effective confining stress, $K_{0}\left(=1-\sin \emptyset^{\prime}\right)$ is the coefficient of earth pressure at rest, and $\emptyset^{\prime}$

4 is the drained angle of internal friction. In this study, the mean effective confining stress $\left(\sigma^{\prime}{ }_{c o}\right)$,

5 could be measured directly by the embedded load cells. Now, by using the relationship for

$6 \sigma^{\prime}{ }_{c o}$ in Eq. 6 and then rearranging to obtain an expression for the pore pressure ratio gives:

$7 \quad n_{\Delta u}=\frac{3 \times\left(H_{w}^{t}-h_{w}^{t}\right) \times \gamma_{w}}{\sigma_{m v}^{\prime} \times\left(1+2 K_{0}\right)}$

8 Eq. 5 and 7 indicate that $i_{\Delta u}$ is dependent on the effective confining stress, which is likely to

9 vary significantly with the magnitude of applied cyclic loading that in this study is kept similar

10 for all tests, i.e. $\sigma_{\text {min }}^{\prime}=30 \mathrm{kPa}$ and ${\sigma^{\prime}}_{\text {max }}=70 \mathrm{kPa}$. Figure 9 shows the time histories of $\Delta u$

11 during the cyclic tests where the magnitude of $\Delta u$ accumulates over time and reaches its maximum value at the critical onset of geohydraulic failure, i.e. heave in soil specimen $\mathrm{S}$ and suffusion in rest of the specimens. Notably, specimens S and MS had relatively smaller and

14 similar values of $\Delta u$ at all frequencies, unlike MU and $\mathrm{U}$, which had greater magnitudes of $\Delta u$ and larger variations at higher frequencies. This shows that $\mathrm{S}$ and MS can be considered as more suitable protective filters in severe cyclic conditions rather than MU and U. Nevertheless, the decreasing trends of $\Delta u$ after the inception of failure indicate a release of strain energy, which is consistent with the previously discussed sudden variations in axial strain histories. Figure 10 shows the variations in the magnitudes of $\Delta u, n_{\Delta u}$, and $i_{\Delta u}$ induced due to the simulated cyclic loading frequencies and associated train speeds for a standard gauge track. Additional results from Israr et al. (2016) are also plotted in Fig. 10, and all these results are summarised in Table 1. 


\section{Proposed Model}

2 The cyclic loads impart a significant magnitude of strain energy to the soil specimens during

3 loading and unloading cycles, as shown by the axial strain histories discussed in the previous

4 sections (see Figs. 4 and 5). While some portion of this energy dissipates safely due to drag and

5 the frictional characteristics of soils (Polito et al. 2008), the remaining energy continues to

6 accumulate and this may cause significant pore water pressure to develop (Indraratna et al.

7 2017; Alobaidi and Hoare 1998). In this study, the comparisons between the external and

8 internal hydraulic head losses in a soil specimen can determine the pore pressure generated due

9 to dynamic loading. The following section presents a proposed semi-empirical model to

10 quantify the development of pore water pressure using the framework of strain energy

11 dissipation in granular soils.

12 A normalised pore pressure ratio $\left(n_{\Delta u}\right)$ is introduced to capture the pore water pressure

13 generated due to cyclic loading; this in turn is a function of the initial effective confining stress

$14 \sigma_{c o}^{\prime}$ and the dissipated strain energy per unit volume of soil $\Delta W$ (Berrill and Davis 1985):

$15 n_{\Delta u}=A\left(\frac{\Delta W}{\sigma_{c o}^{\prime}}\right)^{B}$

16 The magnitude of $\Delta W$ can be given by the area under the stress-strain hysteresis curve (Green

17 et al. 2000):

$18 \Delta W=0.5 \times \sum_{i=1}^{n}\left(\sigma_{d, i+1}^{\prime}+\sigma_{d, i}^{\prime}\right)\left(\varepsilon_{a, i+1}-\varepsilon_{a, i}\right)$

19 where, $\Delta W=$ dissipated energy per unit volume of soil

$20 \sigma_{d, i}^{\prime}, \sigma_{d, i+1}^{\prime}=\mathrm{i}^{\text {th }}$ and $\mathrm{i}+1^{\text {th }}$ increments in cyclic deviator stress $\sigma_{\text {min }}^{\prime}$

$21 \varepsilon_{a, i}, \varepsilon_{a, i+1}=\mathrm{i}^{\text {th }}$ and $\mathrm{i}+1^{\text {th }}$ increments in axial strain

$22 n=$ total number of load increments

$23 A$ and $\mathrm{B}=$ Empirical coefficients determined from hydraulic tests under cyclic loading. Given

24 the magnitude of cyclic deviator stress was constant, Eq. 9 becomes: 
$1 \quad \Delta W=\Delta \sigma_{d}^{\prime} \sum_{i=1}^{n}\left(\varepsilon_{a, i+1}-\varepsilon_{a, i}\right)$

$2 \Delta W=\Delta \sigma_{d}^{\prime} \times \varepsilon_{a}$

3 The net axial strain $\left(\varepsilon_{a}\right)$ evolves with time by dynamic compaction due to cyclic loading, and

4 as a function of the number of loading cycles and frequency. During 1-dimensional

5 compression, the axial strain evolves rapidly until the elastic shakedown level (permanent

6 plastic deformation) is reached, and then becomes constant (purely elastic). Using an

7 exponential function for axial strain in Eq. 11 yields (Trani and Indraratna 2010):

$8 \Delta W=\Delta \sigma_{d}^{\prime} \times \varepsilon_{f}\left(1-e^{-t f / k_{n}}\right)$

9 where, $t=$ Time for the application of cyclic loading (sec)

$10 f=$ Cyclic loading frequency $(\mathrm{Hz})$

$11 k_{n}=$ Scaling factor equal to $N_{\max } / 10$

$12 N_{\max }=$ Maximum number of load cycles applied to the soil.

13 Substituting Eq. 12 into Eq. 8 gives:

$14 \quad n_{\Delta u}=A\left(\frac{\Delta \sigma_{d}^{\prime} \times \varepsilon_{f}\left(1-e^{-t f / k_{n}}\right)}{\sigma_{\min }^{\prime}}\right)^{B}$

\section{Model Parameters}

16 In Eq. 13 above, the empirical factor $A$ is the cyclic loading coefficient, which accounts for the

17 magnitude of applied mean cyclic stress $\sigma_{m v}^{\prime}$ and is given by (Israr 2016):

$18 \quad A=\sigma_{\text {mean }}^{\prime} / 10=\left(\frac{\sigma_{\min }^{\prime}+\sigma_{\text {max }}^{\prime}}{2}\right) / 10$

19 where $\sigma_{\min }^{\prime}$ and $\sigma_{\max }^{\prime}$ represent the magnitudes of minimum and maximum cyclic loads (i.e.

20 unloading and loading), respectively. 
1 The empirical factor $B$ is the hydraulic conductivity coefficient, which captures the reduction

2 in permeability due to dynamic compaction under cyclic loading. Figure 11 shows the

3 correlation between $B$ and the permeability reduction ratio $k_{i} / k_{f}$ which results from the cyclic

4 densification of the current test results. The following empirical linear relationship is observed

5 with a high coefficient of correlation (i.e. $\mathrm{R}^{2}>0.95$ ):

$6 \quad B=0.065\left(\frac{k_{i}}{k_{f}}\right)+0.60$

7 where $k_{i}$ and $k_{f}$ define the initial permeability and the final permeability due to cyclic

8 densification (i.e. before the inception of geohydraulic failure), respectively.

\section{Discussion and Model Validation}

10 Figure 12 shows the cyclic response of current samples that can be divided into three distinct 11 phases, as follows:

12 (I) Pre-shakedown: cyclic densification occurs in the form of permanent deformation (i.e. axial strain) and the soil response remains purely plastic,

14 (II) Post-shakedown: cyclic loading does not incur permanent deformations and the soil response remains elastic. Nonetheless, the physical impact of vibrations may result into rearrangement of particles and yield negligible axial strain compared to phase-I, as observed in some of the current test results.

(III) Post-critical: geohydraulic failures occur such as heave in internally stable and suffusion in unstable soils. Permanent deformation occurs such as marked axial strain due to cyclic densification and internal erosion in tandem and the soil response is purely plastic, just like phase-I.

In essence, during phases I and III, the specimen response remains generally identical and may 
1 dissipation (A-D) from phase I to III continues, and the net result is in the form of excessive

2 settlement due to accumulated axial strains. Figure 13 shows the mechanism of axial strain

3 developing due to the cycles of accumulation and dissipation due to the application of cyclic

4 loading. Nevertheless, the resulting axial strain may exceed tolerable serviceability limits for

5 many high-speed track substructures.

6 Not surprisingly, the current specimens initially show permanent (plastic) deformation due to

7 cyclic loading in phase I until they reach elastic shakedown, which occurs in the initial phase

8 of cyclic loading. For instance, sample MU under $20 \mathrm{~Hz}$ cyclic loading (MU-C20) reaches the

9 elastic shakedown level in 180 minutes (i.e. number of load cycles, $\mathrm{N}<220,000$ ), but after this

10 the specimen response remains purely rigid, and there is no variation in axial strain until the

11 inception of geohydraulic failure, that occurs at time $t=500$ minutes (i.e. $N=600,000$ ). As a

12 result of failure (i.e. heave or suffusion), the specimens show marked permanent deformation

13 in the form of significant axial strain, as shown by the increasing trends of strain histories

14 discussed in the previous sections. For instance, up to $2.33 \%$ of axial strain is recorded in the only cycle of accumulation and dissipation simulated in this study for sample-U (Table 1). In essence, before the soils become unstable, more than 95\% strain energy accumulates in the

17 initial elastic shakedown regime, and the specimens show permanent deformation.

18 The proposed model was validated with the experimental results of this current study (Table 1)

19 and those adopted from the published literature presented (Table 2). The model parameters

20 adopted from both studies are presented separately in Table 3, including the loading frequency

$21 f$, the permeability ratio $k_{i} / k_{f}$, the cyclic loading coefficient $A$ and the hydraulic conductivity

22 factor $B$. For the data reported in Table 3, Fig. 14 plots the observed $n_{\Delta u}$-values against those

23 predicted from Eq. 13. As shown, there is a close agreement between the two $n_{\Delta u}$-values, where 
1 most data points closely follow the line of equality with less than $6 \%$ standard error of mean;

2 this may be acceptable as a preliminary analysis for most practical purposes.

\section{Limitations of this Study}

4 This study is focused on the analysis of granular soils subjected to simultaneous one-

5 dimensional upward flow and downward mechanical loading, which in practice would simulate

6 real life subballast filter and drainage layers in railway substructures. Note that the hydro-

7 mechanical equilibrium and the inclined seepage paths in full-scale problems may be quite

8 different from those considered here for simplified laboratory modelling, which is often one-

9 dimensional. In this study, a fixed magnitude of sinusoidal load, i.e. $\sigma_{\min }^{\prime}=30, \sigma_{\max }^{\prime}=$

$1070, \sigma_{d e v}^{\prime}=40$ and $\sigma_{\text {mean }}^{\prime}=50 \mathrm{kPa}$ with a cyclic stress ratio of 0.67 and frequency up to 30

$11 \mathrm{~Hz}$ was applied to simulate a heavy-haul train operating at speeds up to $210 \mathrm{~km} / \mathrm{hr}$ on a standard

12 gauge track. Nonetheless, as a common limitation for most laboratory studies, the scale of the

13 testing may not be comparable to the actual dimensions of most practical problems.

\section{Conclusions}

15 This study attempted to model the generation of pore water pressure in subballast filters

16 subjected to cyclic loading at varying frequencies in the laboratory, and presented a framework

17 to investigate the generation of pore pressure in soft saturated subgrades. Based on the principal

18 findings of the current results, the proposed model and its validation, the following conclusions

19 can be drawn:

The application of static loading stabilised the specimens by increasing the magnitude

21 of critical hydraulic gradients $\left(i_{c r}\right)$, whereas cyclic loading tended to destabilise them by

22 decreasing the magnitudes of $i_{c r}$ for geohydraulic failures. For instance, only specimen $\mathrm{U}$ could

23 be characterised as internally unstable under static conditions, while under cyclic loading, only

24 specimen $\mathrm{S}$ showed internal stability. 
$1>$ In addition to constant physical perturbation, cyclic loading induced significant build-

2 up of excess pore pressure as a function of loading frequency. The other factors, which

3 markedly influenced the generation of pore pressure, included reduced permeability attributed

4 to cyclic densification, the number of loading cycles, and the axial compression of specimens.

$5>$ The pore pressure induced at higher frequencies (10 to $30 \mathrm{~Hz})$ triggered excessive

6 internal erosion in the current specimens, which caused premature suffusion in internally

7 unstable and marginal soils (MS and MU). Nonetheless, despite showing internal stability

8 during the static tests, both MS and MU suffered from severe internal erosion under cyclic

9 conditions and therefore deemed internally unstable.

$10>$ In this study, the compression of specimens under cyclic loading could be divided into

11 three distinct phases before and after the elastic shakedown level; namely (I) pre-shakedown

12 plastic, (II) post-shakedown elastic, and (III) post-critical plastic phases. All the reductions in

13 porosity and permeability due to cyclic densification occur in the plastic phases I and III, where

14 strain energy accumulates. Maximum pore pressure generates in the elastic phase II where the

15 specimens possess minimum hydraulic conductivities.

$16>$ The cyclic strain energy is released to induce pore water pressure as a function of the

17 permeability reduction and effective confining stress. In this regard, an energy based pore

18 pressure model has been proposed and successfully validated through current and published

19 test results.

$20>$ Notably, four out of seven soils examined in this study exhibited internal instability

21 during cyclic filtration tests (i.e. MS, MU, U and G). This implies that the current industry 22 practices for selecting subballast filters may include significant potential for internal instability

23 under cyclic loading.

24 The current model can reasonably estimate the excess pore pressure and facilitate hydromechanical assessment of internal stability to ensure the longevity of subballast filters under 
1 cyclic loading conditions. However, its applications to naturally erodible subgrade soils under

2 different conditions warrant further investigations. While the current propositions may be

3 recommended as a reliable tool for preliminary analysis only prior to detailed investigations,

4 caution must still be exercised when applying the proposed model to soils with markedly

5 different properties in field problems.

6

$7 \quad$ Acknowledgement

8 The financial support provided in the form of Faculty Development Program and International

9 Postgraduate Tuition Award scholarships by University of Engineering and Technology

10 Lahore (Pakistan) and University of Wollongong (Australia), respectively. The technical

11 support from laboratory staff of Centre for Geomechanics and Railway Engineering (GRE),

12 University of Wollongong, is gratefully acknowledged. 


\section{Notation}

2 Following symbols are used in this paper:

$3 \quad$ CSD and PSD = Particle and constriction size distributions, respectively;

$4 \quad C_{u}=$ Coefficient of uniformity;

$5 \quad D_{C}=$ hydraulic cell diameter $(\mathrm{mm})$;

$6 \quad d_{85, A S}^{f}=85^{\text {th }}$ percentile finer by surface area $(\mathrm{mm})$;

$7 \quad d_{c 35}^{c}=$ controlling constriction size of coarser fraction $(\mathrm{mm})$;

$8 d_{x}=$ Particle size corresponding to $\mathrm{x}$ percentile finer by mass ( $\left.\mathrm{mm}\right)$;

$9 \quad e_{\min }=$ Minimum index void ratio;

$10 f=$ Cyclic loading frequency $(1 / \mathrm{sec})$;

$11 \quad H_{C}=$ Hydraulic cell height $(\mathrm{mm})$;

$12 h_{f}=$ Thickness of soil sample $(\mathrm{mm})$;

$13 h_{w}^{\text {in }}$ and $h_{w}^{\text {out }}=$ Inflow and outflow hydraulic head losses, respectively (m);

$14 h_{w}^{t}$ and $H_{w}^{t}=$ Sum of external and internal head losses, respectively (m);

$15 i, i_{a}$ and $i_{i j}=$ Expressions for applied, average and local hydraulic gradients, respectively;

$16 i_{c r, \exp }$ and $i_{\Delta u}=$ Observed critical and pore pressure hydraulic gradients, respectively;

$17 i_{c r, i j}$ and $i_{c r, a}=$ Local and average critical hydraulic gradients, respectively;

$18 K_{0}=$ Coefficient of earth pressure at rest;

$19 k_{i}$ and $k_{f}=$ Initial and final hydraulic conductivity $(\mathrm{m} / \mathrm{sec})$;

$20 \quad k_{n}=$ Scaling factor;

$21 \quad N$ and $N_{\max }=$ Number of cycles and maximum number of cycles applied, respectively;

$22 n=$ Total number of load increments;

$23 Q_{e}=$ Volumetric flow rate of effluent $(\mathrm{m} 3 / \mathrm{sec})$;

$24 \quad R_{d}=$ Relative density of soil; 
$1 \quad p_{w}^{i}$ and $p_{w}^{j}=$ Hydraulic pressures at ${ }^{\mathrm{i}}$ th and ${ }^{\mathrm{j}}$ th points, respectively $(\mathrm{kPa})$;

$2 p_{w}^{\text {in }}$ and $p_{w}^{\text {out }}=$ Inflow and outflow hydraulic pressure, respectively $(\mathrm{kPa})$;

$3 \mathrm{R}=$ Ratio of cell diameter and largest particle size;

$4 \quad n_{\Delta u}=$ Normalized pore water pressure ratio;

$5 t=$ Time of application of cyclic loading (sec);

$6 \gamma_{w}$ and $\gamma_{s}=$ Unit weights of water and soil, respectively $\left(\mathrm{kN} / \mathrm{m}^{3}\right)$;

$7 \quad \varepsilon_{a, i+1}$ and $\varepsilon_{a, i}=$ The $\mathrm{i}^{\text {th }}$ and $\mathrm{i}+1^{\text {th }}$ increments in axial strain, respectively;

$8 \quad \varepsilon_{f}=$ Frictional component of axial strain;

$9 \sigma_{d, i}^{\prime}$ and $\sigma_{d, i+1}^{\prime}=$ The $\mathrm{i}^{\text {th }}$ and $\mathrm{i}+1^{\text {th }}$ increments in cyclic deviator stress, respectively $(\mathrm{kPa})$;

$10 \sigma_{v}^{\prime}, \sigma_{\text {min }}^{\prime}, \sigma_{\text {max }}^{\prime}, \sigma_{\text {dev }}^{\prime}$ and $\sigma_{\text {mean }}^{\prime}=$ Expressions for vertical, minimum, maximum, deviator

11 and mean effective stresses, respectively $(\mathrm{kPa})$;

$12 \sigma_{c o}^{\prime}$ and $\sigma_{m v}^{\prime}=$ Effective confining and mean vertical effective stresses, respectively (kPa);

$13 \emptyset^{\prime}=$ Drained angle of internal friction (degrees);

$14 \Delta \sigma_{d}^{\prime}=$ Mean deviator stress $(\mathrm{kPa})$;

$15 \Delta W=$ Strain energy per unit volume;

$16 \Delta u=$ Excess pore water pressure $(\mathrm{kPa}) ;$ and

$17 \Delta y=$ thickness or depth of soil layer $(\mathrm{mm})$. 


\section{References}

2 Alobaidi, I. M., and Hoare, D. J. (1998). "Qualitative criteria for anti-pumping geocomposites."

3 Geotextiles and Geomembranes., 16, 221-245.

4 American Society for Testing and Materials (ASTM). (2006) "Standard test methods for maximum

5 index density and unit weight of soils using a vibratory table," ASTM D4253-06, West

6 Conshohocken, Pa.

7 Berrill, J. B., and Davis, R. O. (1985). "Energy dissipation and seismic liquefaction of sands:

8 revised model." Soils Found., 25(2), 106-118.

9 Burenkova, V. V. (1993). “Assessment of suffusion in non-cohesive and graded soils.” Filters in

10 geotechnical and hydraulic engineering, J. Brauns, M. Heibaum, and U. Schuler, eds., Bakema,

11 Rotterdam, The Netherlands, 357-360.

12 Chang, D. and L. Zhang (2013). "Critical Hydraulic Gradients of Internal Erosion under 13 Complex Stress States.” J. Geotech. Geoenviron. Eng.,139(9), 1454-1467.

14 Christie, D. (2007). "Bulli field trial: Vertical and lateral pressure measurement." Rail CRC

15 Seminar, seminar conducted at the University of Wollongong.

16 Chung Ip, M., Haque, A. and Bouazza, A. (2012). "Influence of cyclic stress pulse shapes on

17 filtration behavior of railway subballast.” J. Geotech. Geoenviron. Eng., 138(2), 230-235.

18 Fourie, A. B., Copeland, A. M., and Barrett, A. J. (1994). "Optimization of the as-placed

19 properties of hydraulic backfill." J. South African Instt. Min. and Met., 94(8), 199-210.

20 Green, R. A., Mitchell, J. K., and Polito, C. P. (2000). “An energy-based pore pressure 21 generation model for cohesionless soils." Proc., John Booker Memorial Symposium-

22 Developments in Theoretical Geomechanics, D. W. Smith and J. P. Carter, eds., Balkema,

23 Rotterdam, The Netherlands, 383-390.

24 Gutenberg, B., and Richter, C. F. (1942). Earthquake magnitude. Intensity, energy and acceleration. Bull. Seimol. Soc. Amer., (32), 163-191. 
1 Haque, A., Kabir, E. and Bouazza, A. (2007). "Cyclic filtration apparatus for testing subballast

2 under rail track." J. Geotech. Geoenviron. Eng, 133(3), 338-341.

3 Indraratna, B., Israr, J., and Li, M. (2017). "Inception of geohydraulic failures in granular soils4 an experimental and theoretical treatment." Geotechnique, 5 http://dx.doi.org/10.1680/jgeot.16.P.227 (In Press).

6 Indraratna, B., Israr, J., and Rujikiatkamjorn, C. (2015). "Geometrical method for evaluating

7 the internal instability of granular filters based on constriction size distribution." J. Geotech.

8 Geoenviron. Eng., (DOI: 10.1061/(ASCE)GT.1943-5606.0001343), 1-14.

9 Indraratna, B., Nguyen, V. T., and Rujikiatkamjorn, C. (2012). "Hydraulic conductivity of 10 saturated granular soils determined using a constriction-based technique." Can. Geotech. J. 11 49(5), 607-613.

12 Israr, J. (2016). Internal instability of granular filters under cyclic loading. PhD thesis, 13 University of Wollongong, Wollongong, Australia.

14 Israr, J., and Indraratna, B. (2017). Internal stability of granular filters under static and cyclic 15 loading. J. Geotech. Geoenviron. Eng., 04017012 (DOI: 10.1061/(ASCE)GT.1943$165606.0001661)$.

17 Israr, J., Indraratna, B., and Rujikiatkamjorn, C. (2016). "Laboratory modelling of the seepage 18 induced response of granular soils under static and cyclic conditions" Geotech. Testing. J., 39(5), 1-18 (DOI: 10.1520/GTJ20150288)

20 Kenney, T. C., and Lau, D. (1985). "Internal stability of granular filters." Can. Geotech. J., 22, $21 \quad 215-225$.

Koerner, G. R., Koerner, R. M., and Martin, J. P. (1994). “Design of landfill leachate- collection filters.” J. Geotech. Geoenviron. Eng., 120, No. 10, 1792-1803.

24 Moffat, R. and Fannin, R. J. (2011). "A hydromechanical relation governing the internal 25 stability of cohesionless soil.” Can. Geotech. J. 48, No. 3, 413-424. 
1 Nemat-Nasser, S., and Shokooh, A. (1979). "A Unified Approach to Densification and

2 Liquefaction of Cohesionless Sand in Cyclic Shearing." Canadian Geotechnical Journal 16: $3 \quad 659-678$.

4 Polito, C. P., Green, R. A., and Lee, J. (2008). "Pore pressure generation models for sands and 5 silty soils subjected to cyclic loading." J. Geotech. Geoenviron. Eng., 134(10), 1490-1500.

6 Sansalone, J., Kuang, X., and Rainieri, V. (2008). "Permeable pavement as a hydraulic and 7 filtration interface for urban drainage.” J. Irrig. Drain. Eng. 134(5), 666-674.

8 Sassa, S., and Sekiguchi, H. (1999). "Wave-induced liquefaction of beds of sand in a 9 centrifuge." Geotechnique 49(5), 621-638.

10 Seed, H. B., Idriss, I. M., and Arango, I. (1983). "Evaluation of liquefaction potential using 11 field performance data.” J. Geotech. Engrg., 109(3), 458-482. Seed, H.B., and Idriss, I.M. (1971). "Simplified Procedure For Evaluation Soil Liquefaction Potential" Journal of the Soil Mechanics and Foundations Division, 97(9), 1249-1273.

14 Selig, E. T., and Waters, J. M. (1994). Track geotechnology and substructure management. 15 London: Thomas Telford.

16 Trani, L. D. O. and Indraratna, B. (2010). “Assessment of Subballast Filtration under Cyclic 17 Loading.” J. Geotech. Geoenviron. Eng, 136(11), 1519-1528.

18 Xiao, M. and Shwiyhat, N. (2012). "Experimental investigation of the effects of suffusion on 19 physical and geomechanic characteristics of sandy soils." J. Geotech. Testing. 35(6), 890-900.

20 Xiao, M., Reddi, L.N., and Steinberg, S. (2006). "Effect of vibrations on pore fluid distribution in 21 porous media." Transport in Porous Media, 62(2), 187-204.

22 Youd, T. L., Idriss, I. M., Andrus, R. D., and Arango, I. (2001). "Liquefaction resistance of 23 soils: Summary report from the 1996 NCEER and 1998 NCEER/NSF workshops on evaluation 24 of liquefaction resistance of soils.” J. Geotech. Geoenviron. Eng., 127(10), 817-833. 
1 Zou, Y., Chen, Q., Chen, X., and Cui, P. (2013) "Discrete numerical modelling of particle

2 transport in granular filters." Comput. Geotech., 32(5), 340-57. 


\section{List of Figures}

2 Fig. 1 Illustrations of: (a) transient and residual pore pressures and (b) normalised pore 3 pressure generation ratio with the number of loading cycles.

4 Fig. 2 Soil gradations and current hydraulic test apparatus.

$5 \quad$ Fig. 3 Hydraulic test results for sample U under static loading: (a) Effluent flow rate versus 6 average hydraulic gradients and (b) time evolutions of axial strain due to cyclic densification.

7 Fig. 4 Hydraulic test results for sample U under cyclic loading: (a) Effluent flow rate versus 8 average hydraulic gradients and (b) time evolutions of axial strain due to cyclic densification.

9 Fig. 5 Time evolution of axial compressive strain due to cyclic densification for; (a) 10 sample $\mathrm{S}$ and (b) sample MS.

11 Fig. 6 Time histories of local hydraulic gradients for specimens; (a) U-S50 and (b) U-C5.

12 Fig. 7 Average and local critical hydraulic gradients versus (a) cyclic loading frequency and 13 (b) static effective stress magnitude.

14 Fig. 8 Computing the average and local hydraulic gradients and associated head losses.

15 Fig. 9 Time histories of excess pore water pressure generated under cyclic loading

16 Fig. 10 Observed correlations between cyclic loading frequency (approximate heavy-haul 17 speed) and (a) $i_{\Delta u}$-values, (b) $\Delta u$-values, and (c) $n_{\Delta u}$-values.

18 Fig. 11 Correlation between $B$ and permeability reduction ratio.

19 Fig. 12 Illustrations of (a) Stress-strain hysteresis and (b) time history of axial strain for sample 20 MU-C20. 
1 Fig. 13 Illustration of cumulative settlement resulting from accumulation-dissipation cycles of

2 axial strain energy under cyclic loading.

3 Fig. 14 Comparison between observed and predicted values of $n_{\Delta u}$.

4

\section{$5 \quad$ List of Tables}

6 Table 1. Summary of laboratory test results of this study.

7 Table 2. Summary of laboratory test data adopted from Israr et al. (2016) for validation of 8 current model.

9 Table 3. Parameters for model validation. 


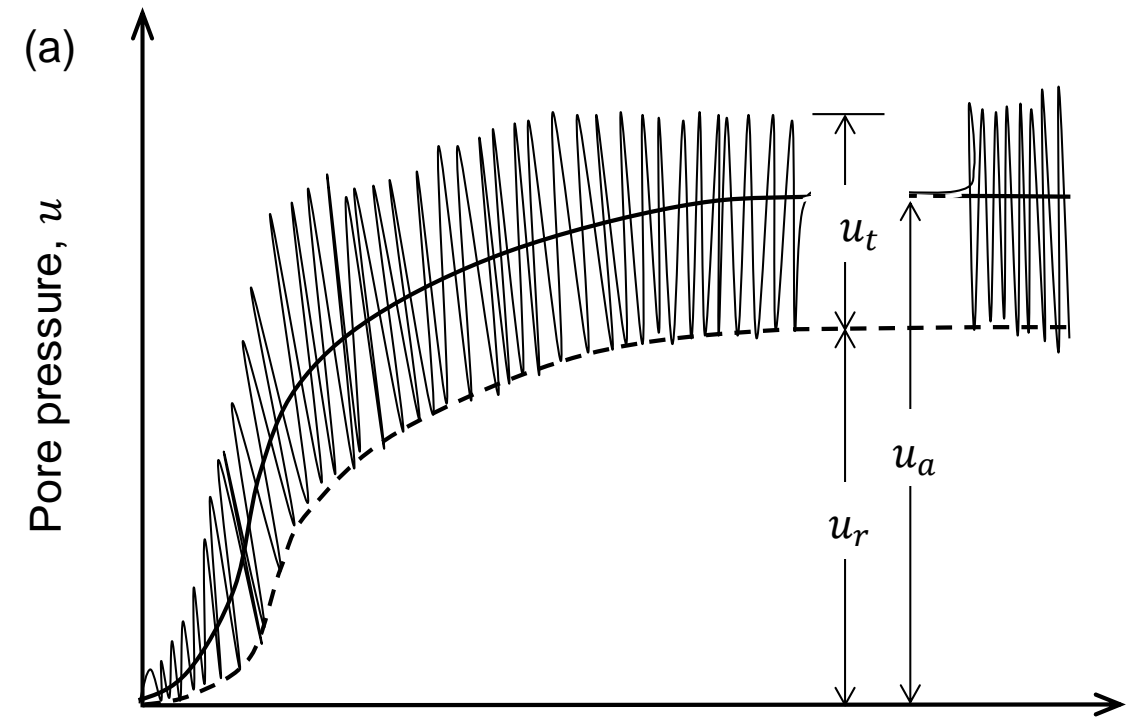

Number of Cycles, $\mathrm{N}$

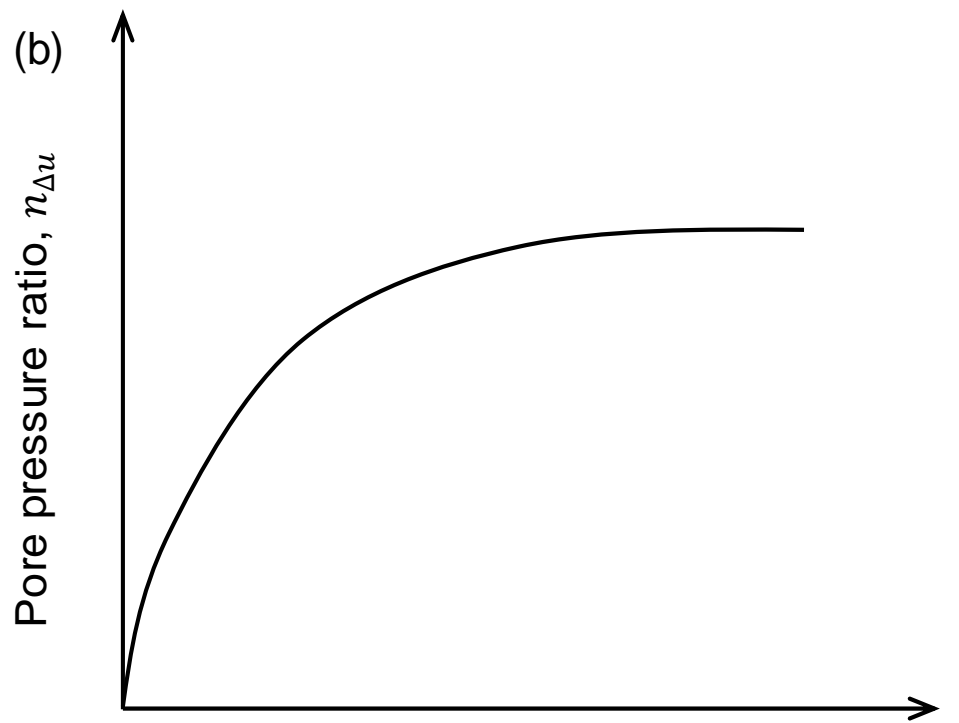

Number of Cycles, $\mathrm{N}$ 


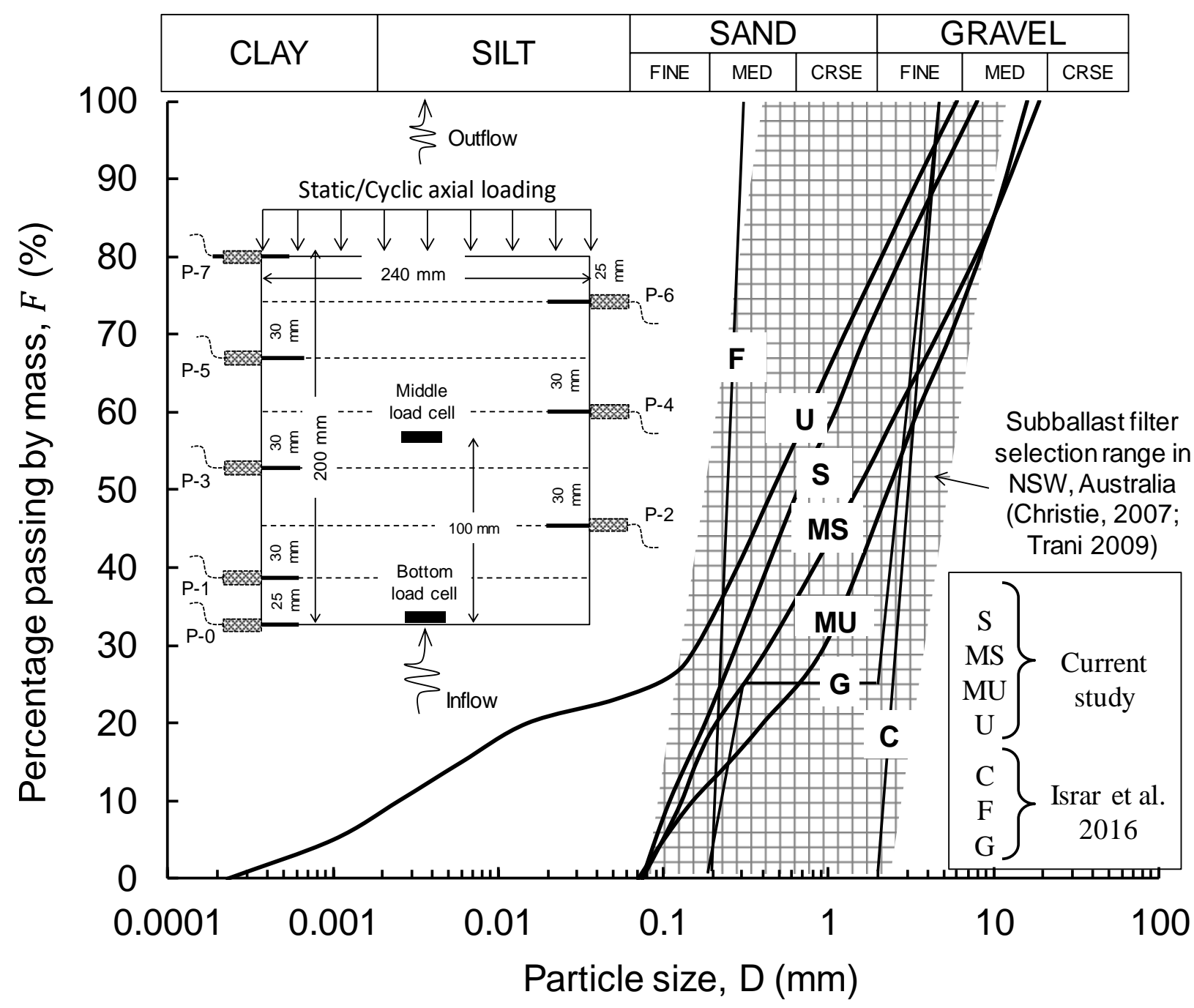




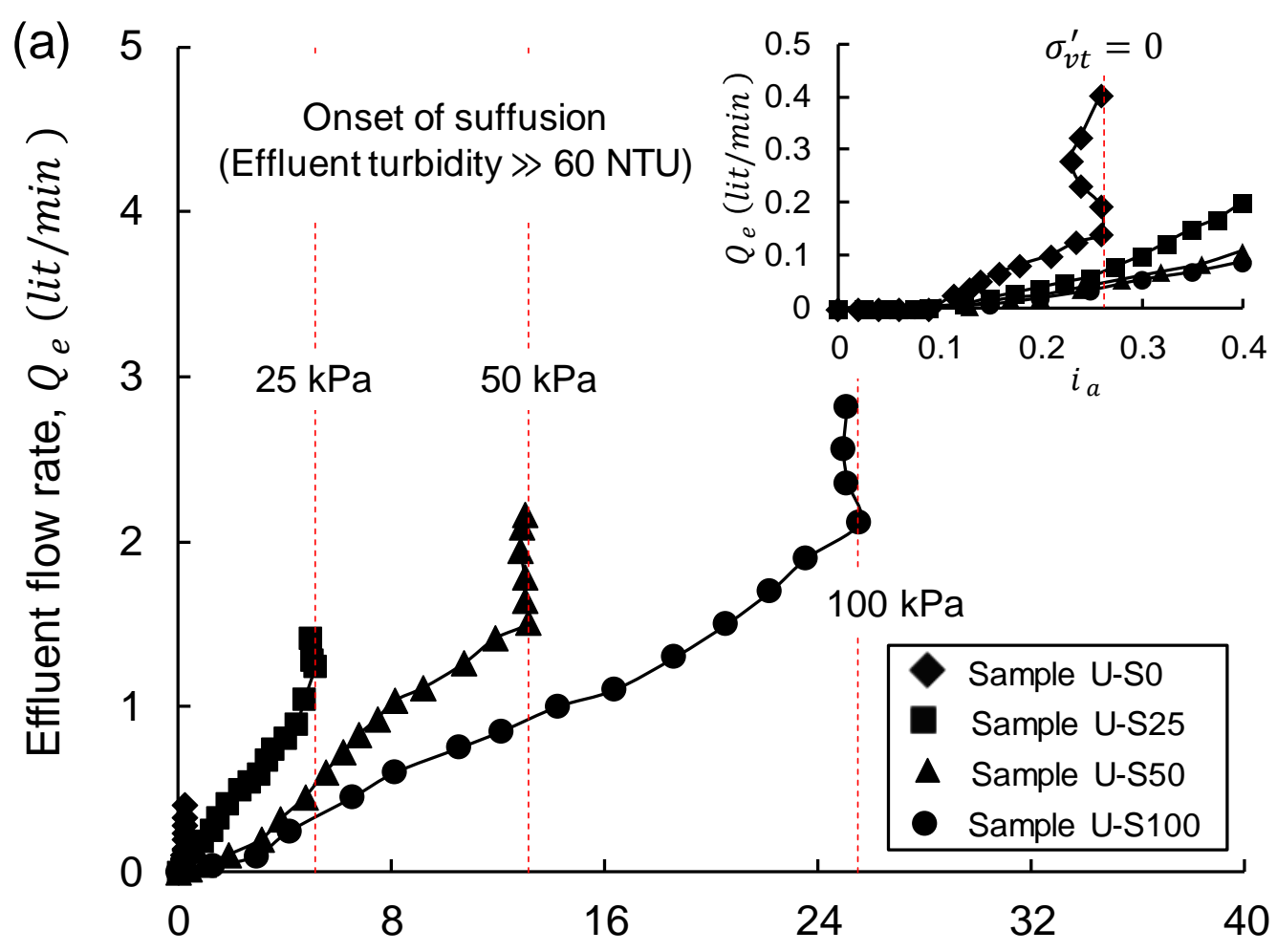

Average hydraulic gradient, $i_{a}$

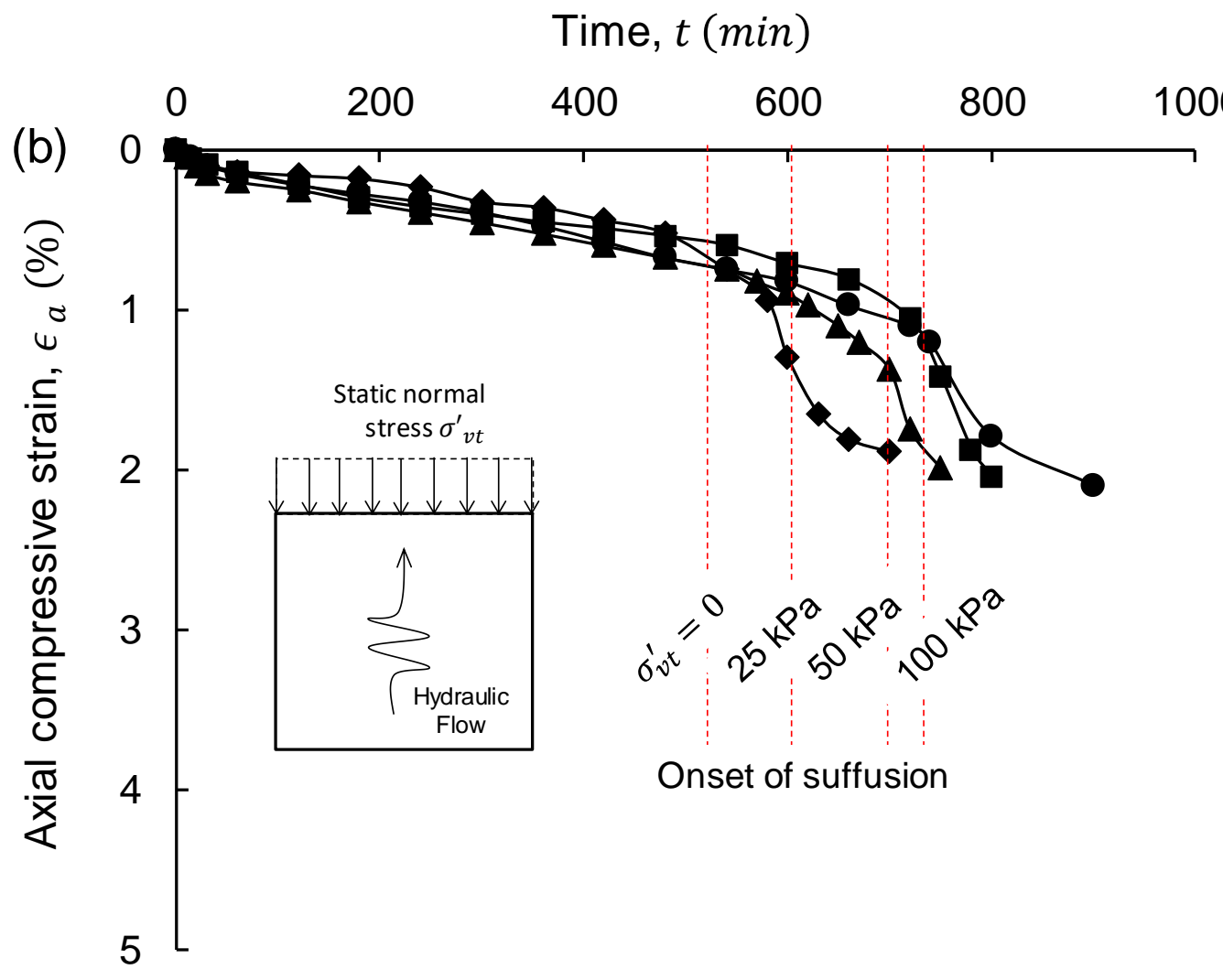



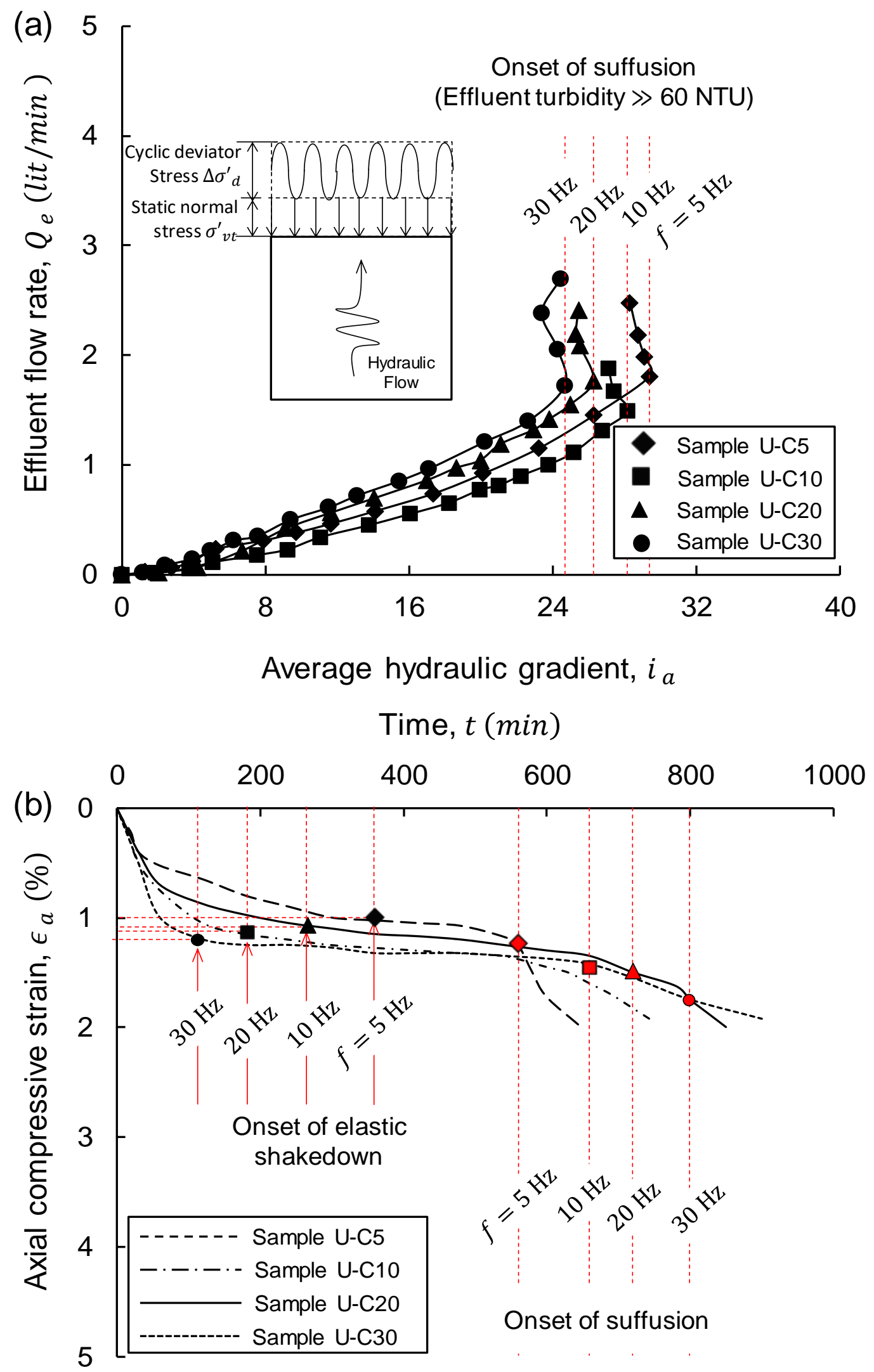

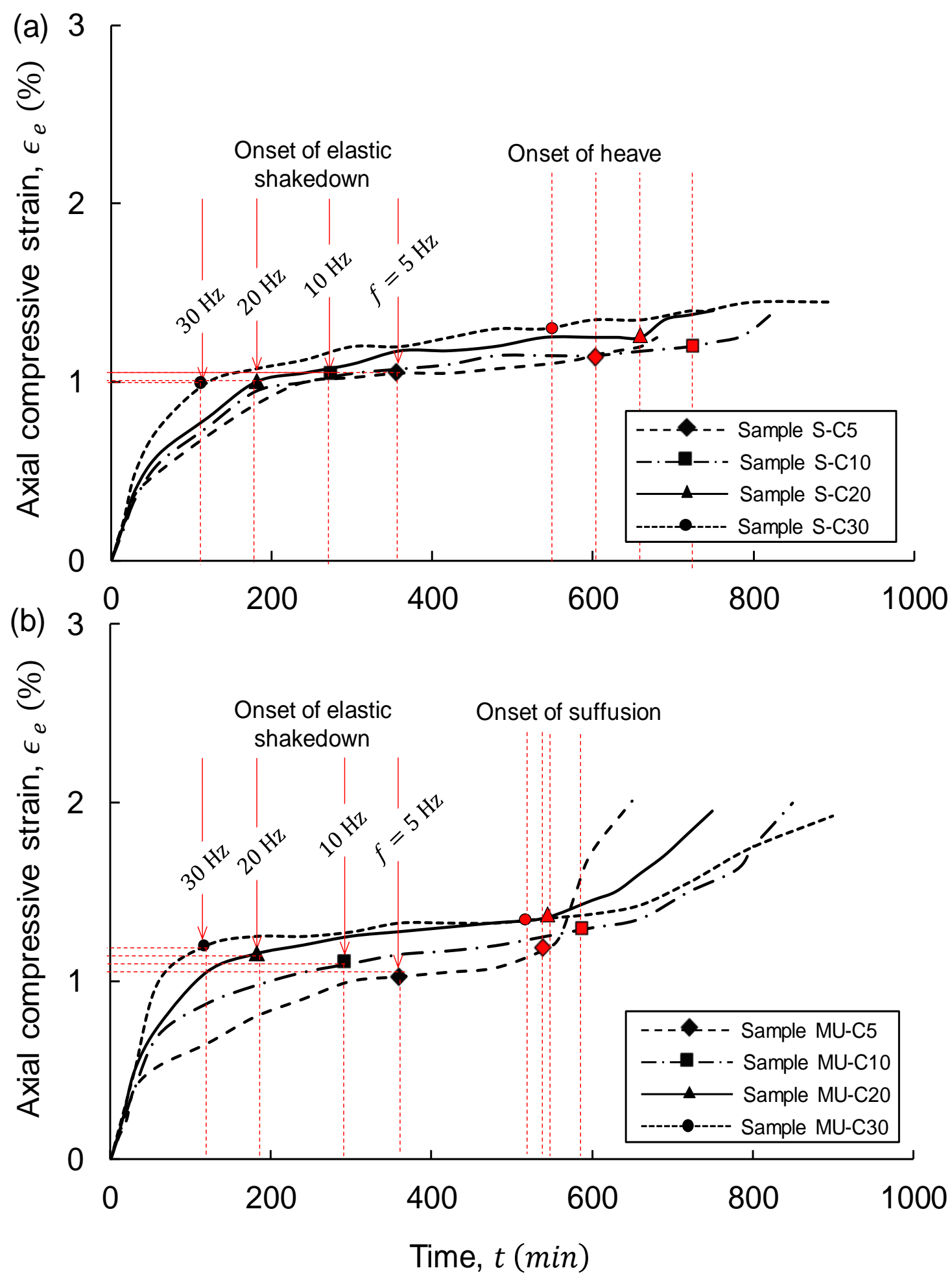

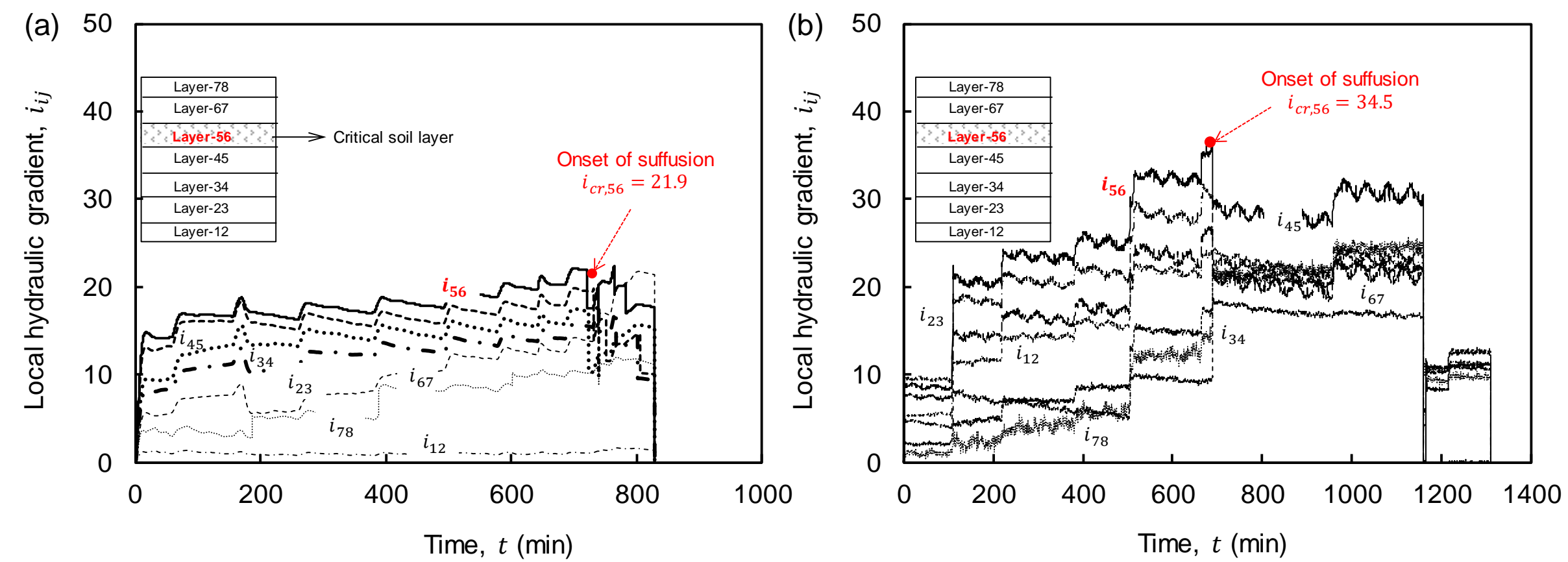

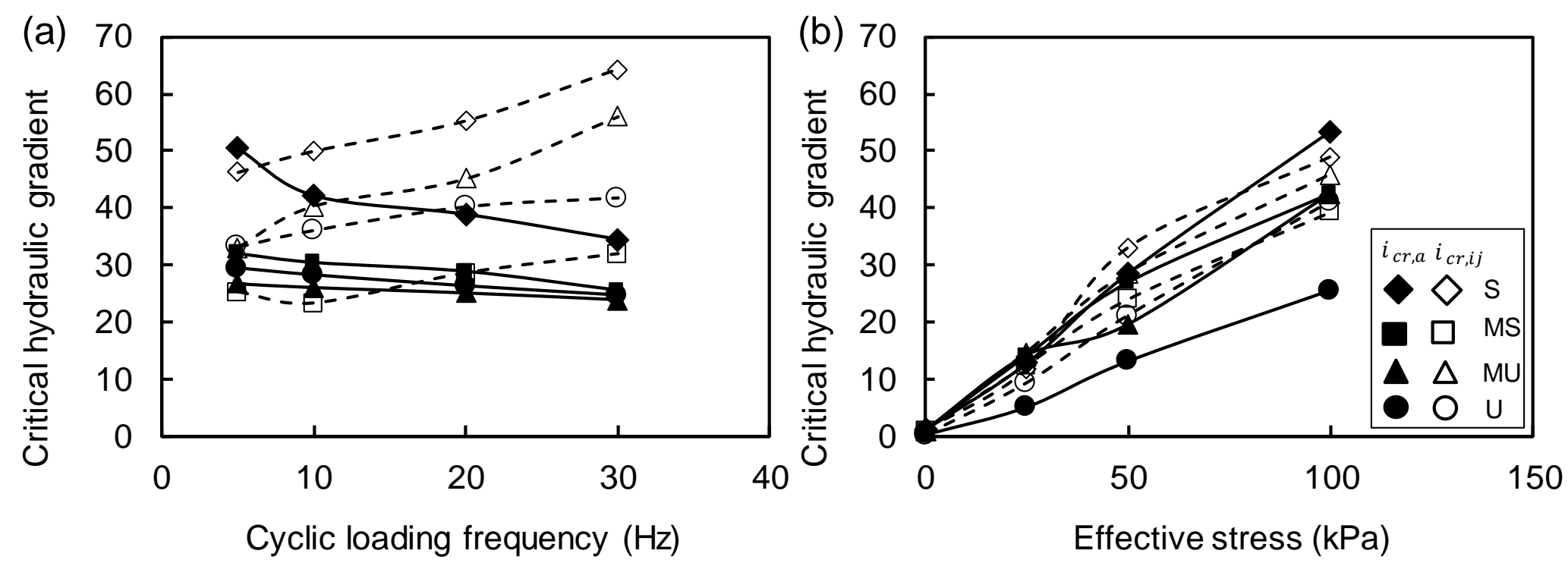

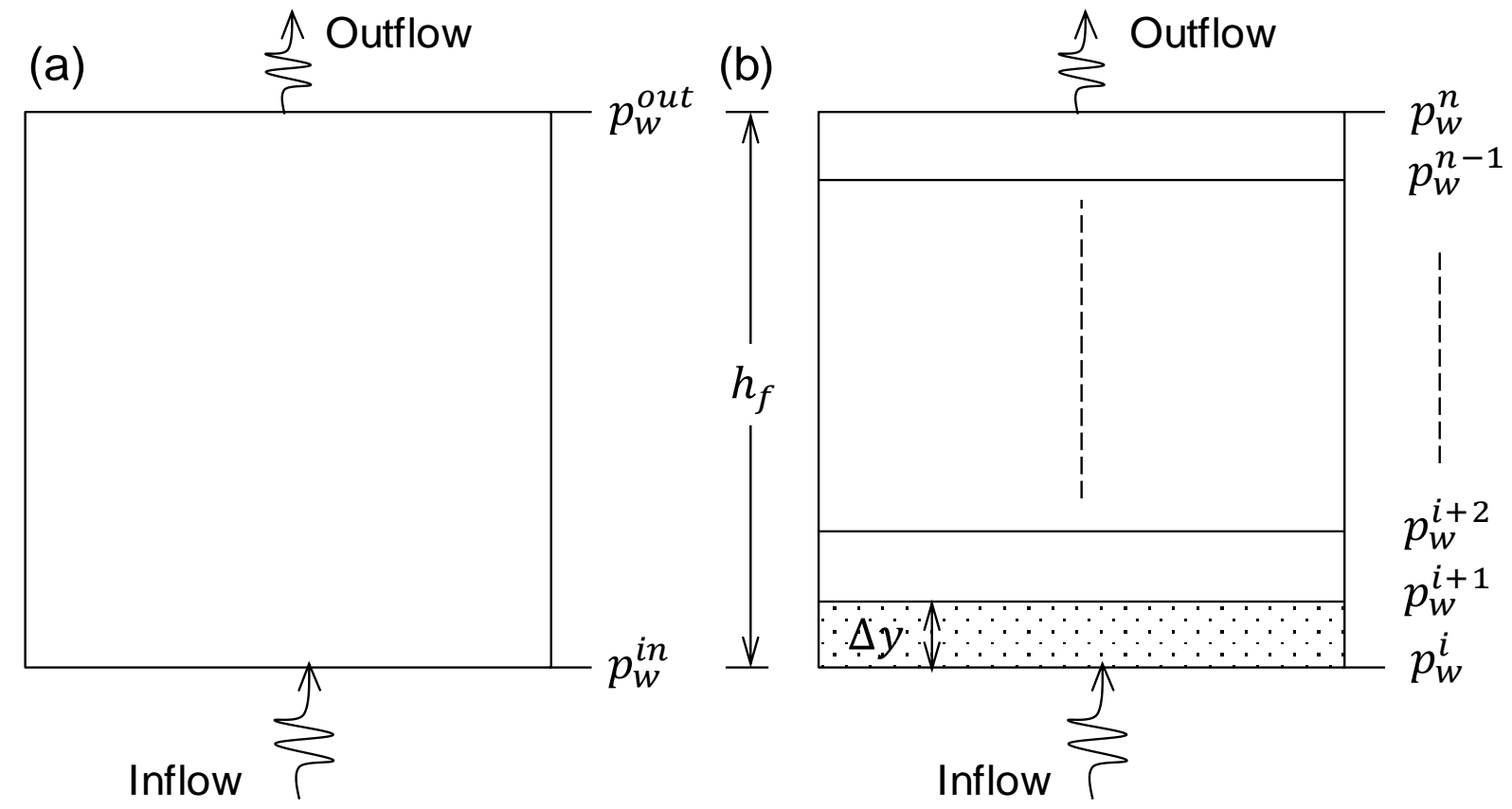

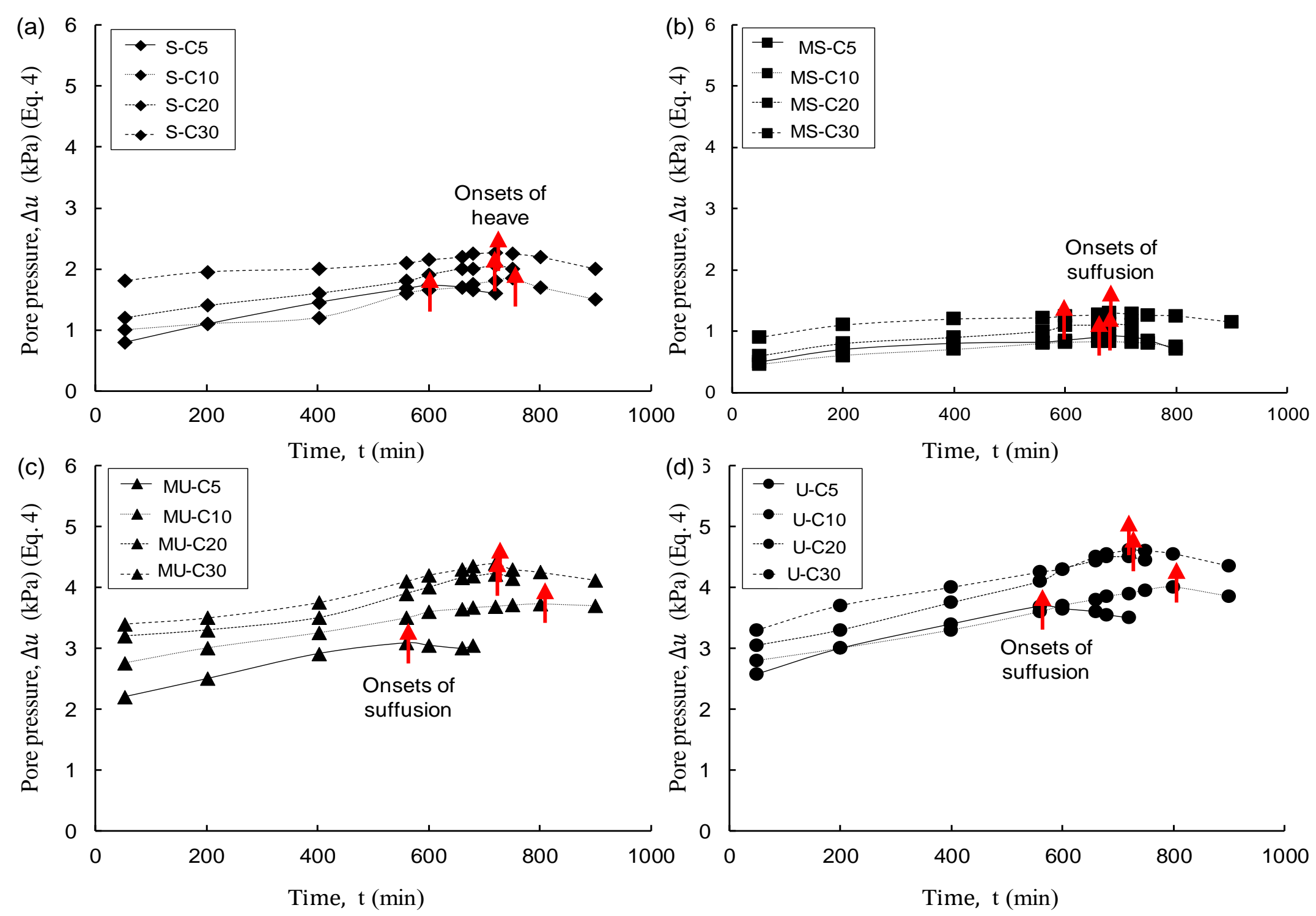
Approximate train speed, $v(\mathrm{~km} / \mathrm{hr})$
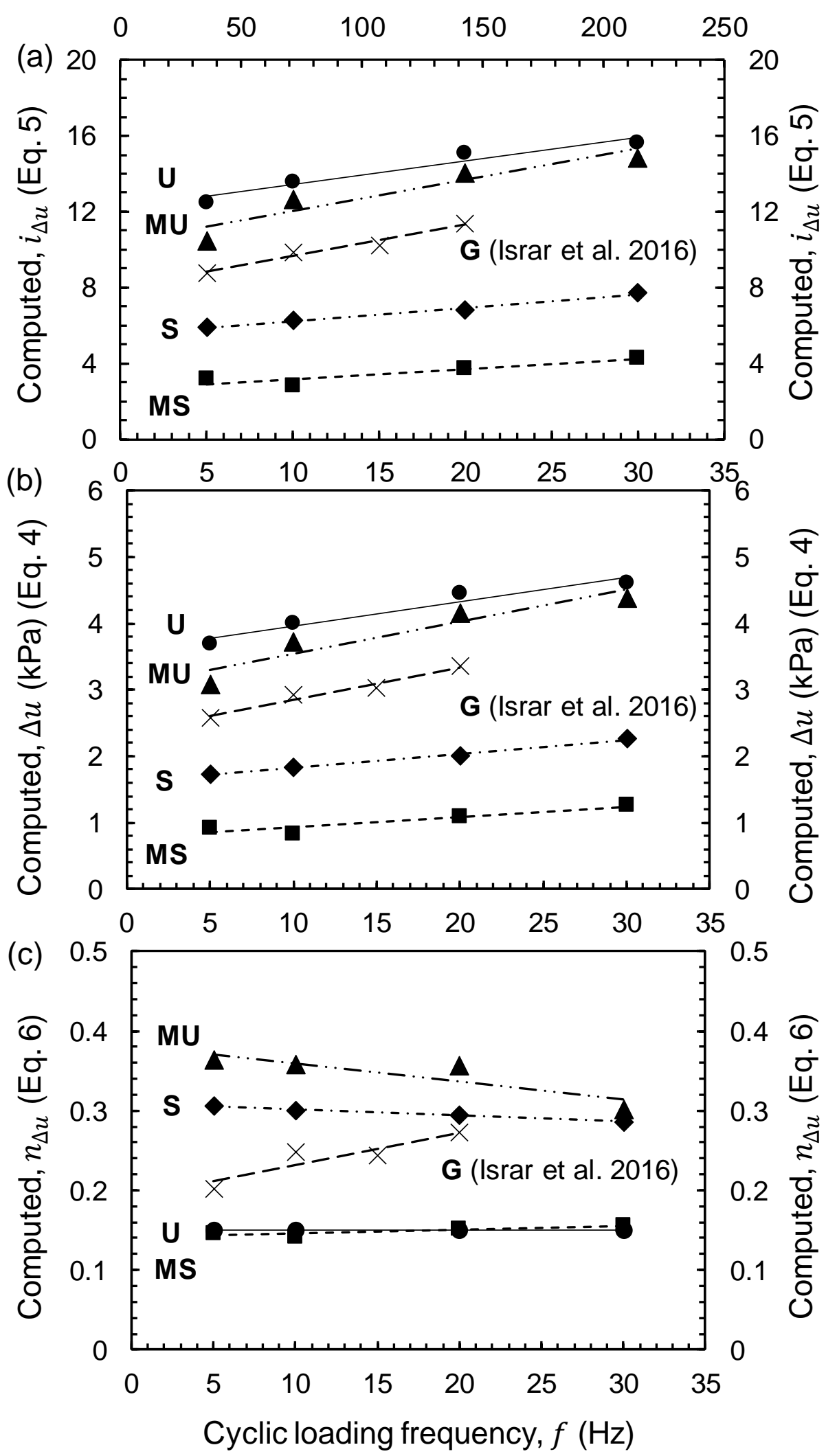

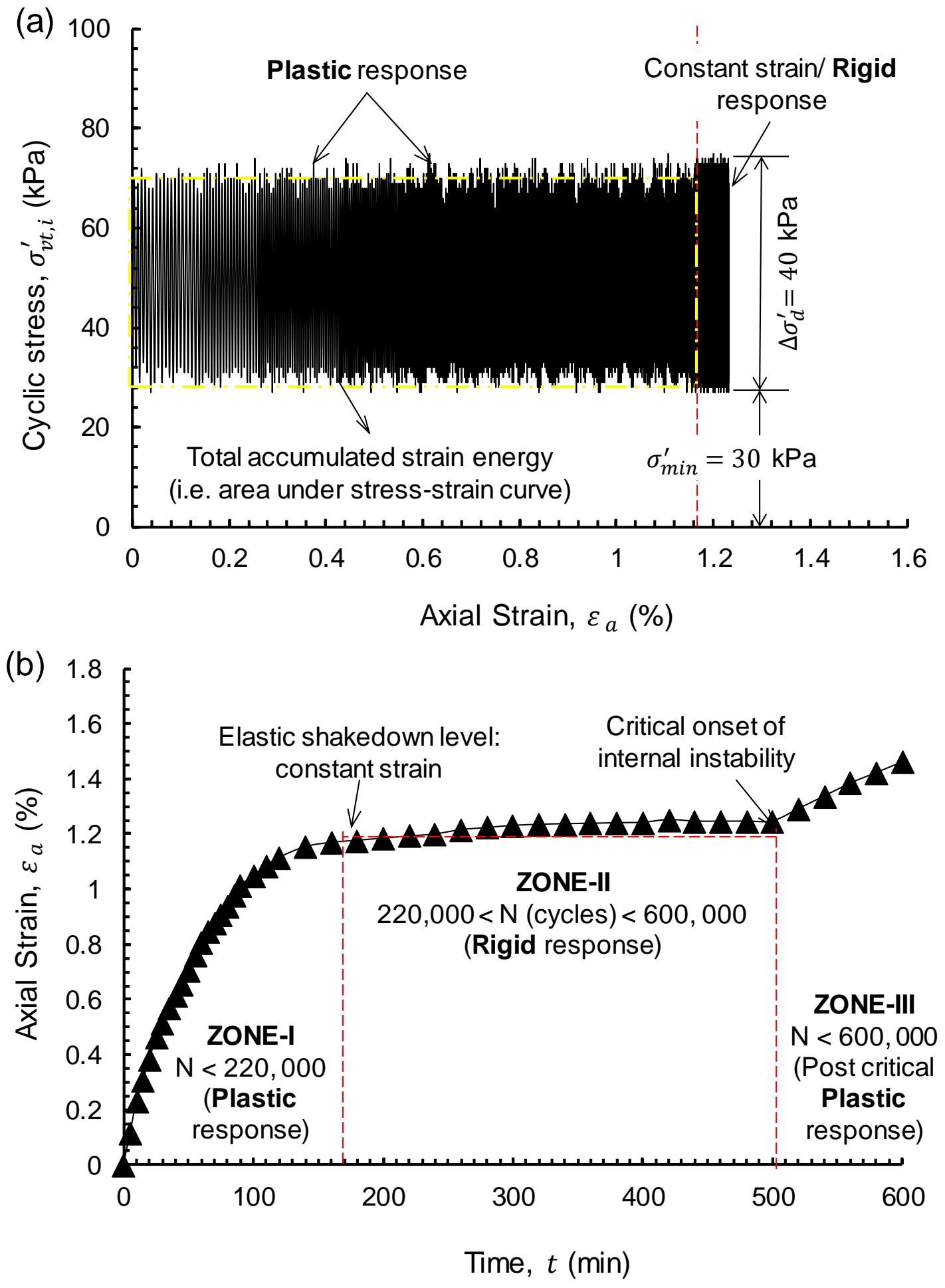


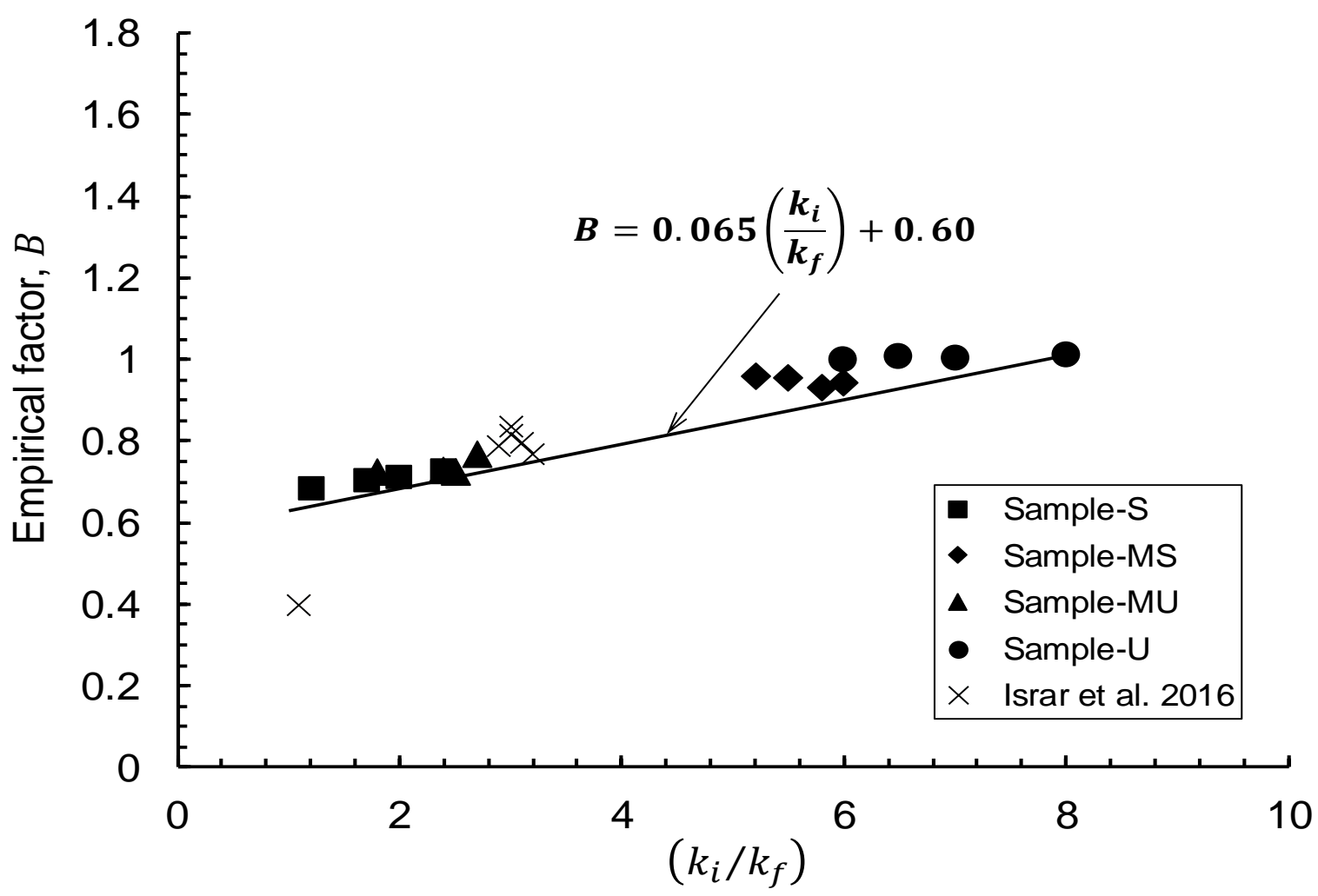




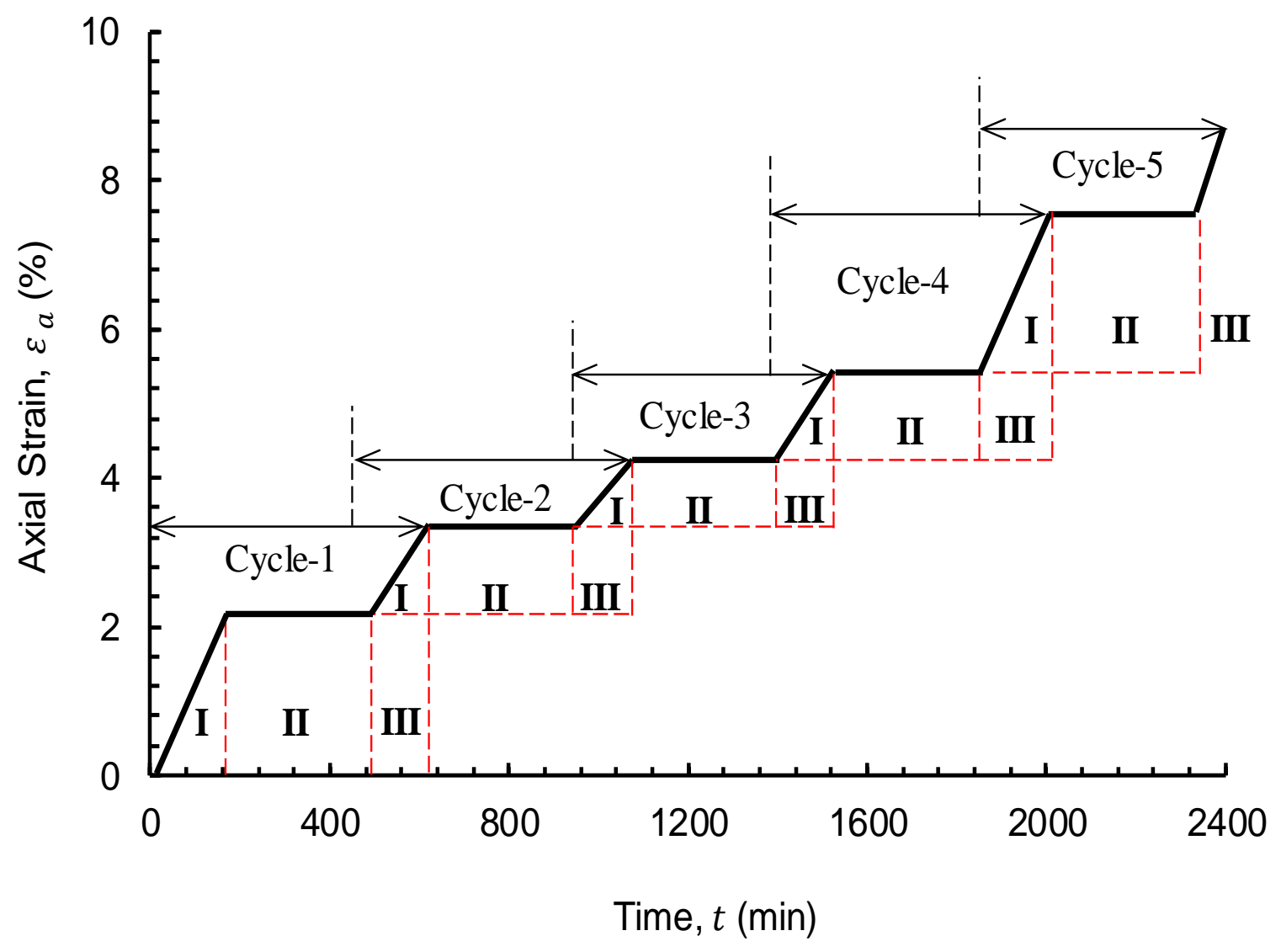




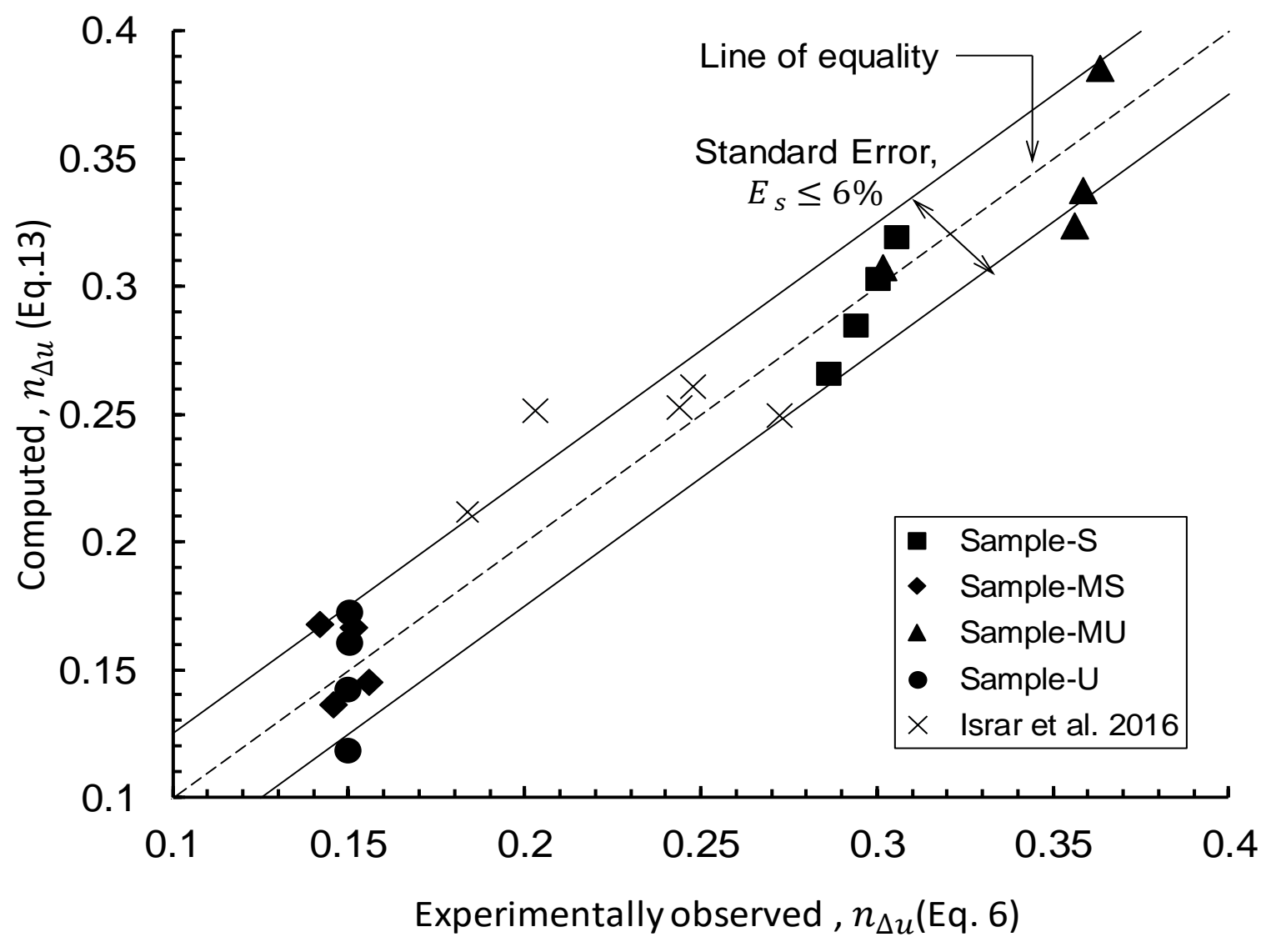


Table 1. Summary of laboratory test results of this study

\begin{tabular}{|c|c|c|c|c|c|c|c|c|c|c|c|c|}
\hline \multirow{2}{*}{$\begin{array}{l}\text { Test } \\
\text { no. }\end{array}$} & \multirow{2}{*}{$\begin{array}{c}\text { Sample } \\
\text { ID }\end{array}$} & \multicolumn{2}{|c|}{$\begin{array}{c}\text { Relative } \\
\text { density (\%) }\end{array}$} & \multirow{2}{*}{$i_{c r, a}$} & \multirow{2}{*}{$i_{c r, i j}$} & \multirow{2}{*}{$i_{\Delta u}$} & \multicolumn{2}{|c|}{$\begin{array}{l}\text { Permeability } \\
\left(\times 10^{-2} \mathrm{~m} / \mathrm{s}\right)\end{array}$} & \multirow{2}{*}{$\begin{array}{c}\text { Internal } \\
\text { erosion } \\
(\%)\end{array}$} & \multirow{2}{*}{$\begin{array}{c}\text { Post-test } \\
\text { Settlement } \\
(\%)\end{array}$} & \multirow[b]{2}{*}{ Failure } & \multirow{2}{*}{$\begin{array}{c}\text { Test } \\
\text { condition }\end{array}$} \\
\hline & & $\begin{array}{l}\text { Pre- } \\
\text { test }\end{array}$ & $\begin{array}{l}\text { Post } \\
\text {-test }\end{array}$ & & & & $k_{\mathrm{i}}$ & $k_{\mathrm{f}}$ & & & & \\
\hline 1 & S-S0 & 96 & 96 & 1.14 & 1.19 & -- & 2.04 & 2.04 & 0.03 & 0.85 & Heave & \multirow{16}{*}{ 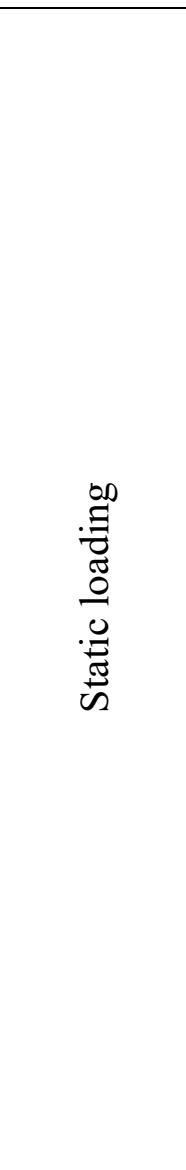 } \\
\hline 2 & S-S25 & 96 & 96 & 12.8 & 12.8 & -- & 1.94 & 1.94 & 0.03 & 1.04 & Heave & \\
\hline 3 & S-S50 & 97 & 97.2 & 28.5 & 35.6 & -- & 1.77 & 1.72 & 0.02 & 0.71 & Heave & \\
\hline 4 & S-S100 & 96 & 97 & 53.4 & 52.7 & -- & 1.54 & 1.47 & 0.01 & 0.93 & Heave & \\
\hline 5 & MS-S0 & 97 & 97 & 1.06 & 1.03 & -- & 1.36 & 1.36 & 2.53 & 0.8 & Heave & \\
\hline 6 & MS-S25 & 98 & 98 & 14.1 & 12.8 & -- & 1.24 & 1.24 & 2.32 & 1.13 & Heave & \\
\hline 7 & MS-S-50 & 97 & 97.2 & 26.9 & 24.6 & -- & 1.17 & 1.11 & 1.71 & 1.11 & Heave & \\
\hline 8 & MS-S100 & 96 & 96.3 & 42.5 & 40.3 & -- & 1.02 & 1 & 1.22 & 1.12 & Heave & \\
\hline 9 & MU-S0 & 98 & 98 & 0.94 & 0.98 & -- & 1.27 & 1.27 & 3.71 & 0.99 & Heave & \\
\hline 10 & MU-S25 & 98 & 98 & 14.1 & 15.2 & -- & 1.19 & 1.19 & 3.05 & 1.06 & Heave & \\
\hline 11 & MU-S50 & 96 & 96.2 & 19.5 & 29.6 & -- & 1.13 & 1.11 & 2.83 & 1.11 & Heave & \\
\hline 12 & MU-S100 & 95 & 95.3 & 42.5 & 47.4 & -- & 1.09 & 1.06 & 2.51 & 1.06 & Heave & \\
\hline 13 & U-S0 & 97 & 97 & 0.26 & 0.23 & -- & 0.04 & 0.042 & 7.37 & 2.01 & Suffusion & \\
\hline 14 & U-S25 & 98 & 98.2 & 5.1 & 9.69 & -- & 0.04 & 0.035 & 8.33 & 1.9 & Suffusion & \\
\hline 15 & U-S50 & 99 & 99.2 & 13.1 & 21.9 & -- & 0.03 & 0.026 & 7.91 & 1.93 & Suffusion & \\
\hline 16 & U-S100 & 98 & 98.4 & 25.5 & 42.6 & -- & 0.01 & 0.011 & 8.89 & 1.93 & Suffusion & \\
\hline
\end{tabular}




\begin{tabular}{|c|c|c|l|l|l|l|l|l|l|l|l|l|}
\hline 17 & S-C5 & 97 & 100 & 50.5 & 49.8 & 5.9 & 1.83 & 1.525 & 0.22 & 1.25 & Heave \\
\hline 18 & S-C10 & 97 & 100 & 42.2 & 53.8 & 6.3 & 1.74 & 1.024 & 0.19 & 1.38 & Heave \\
\hline 19 & S-C20 & 96 & 100 & 38.9 & 59.5 & 6.8 & 1.70 & 0.85 & 0.26 & 1.4 & Heave \\
\hline 20 & S-C30 & 98 & 100 & 34.5 & 69.2 & 7.7 & 1.65 & 0.69 & 0.3 & 1.45 & Heave \\
\hline 21 & MS-C5 & 97 & 100 & 32.1 & 25.9 & 3.1 & 0.95 & 0.164 & 4.11 & 1.68 & Suffusion \\
\hline 22 & MS-C10 & 96 & 100 & 30.5 & 23.9 & 2.8 & 0.9 & 0.173 & 4.33 & 1.81 & Suffusion \\
\hline 23 & MS-C20 & 97 & 100 & 28.9 & 29.3 & 3.7 & 0.86 & 0.156 & 4.52 & 1.93 & Suffusion \\
\hline 24 & MS-C30 & 98 & 100 & 25.5 & 32.7 & 4.3 & 0.83 & 0.138 & 4.76 & 2 & Suffusion \\
\hline 25 & MU-C5 & 98 & 100 & 26.8 & 34.2 & 10.5 & 1.1 & 0.611 & 5.17 & 2.01 & Suffusion \\
\hline 26 & MU-C10 & 97 & 100 & 26.1 & 41.7 & 12.7 & 1.02 & 0.425 & 5.49 & 2 & Suffusion \\
\hline 27 & MU-C20 & 96 & 100 & 25.1 & 46.7 & 14.1 & 0.94 & 0.376 & 5.73 & 1.95 & Suffusion \\
\hline 28 & MU-C30 & 98 & 100 & 23.85 & 57.9 & 14.9 & 0.88 & 0.323 & 5.93 & 1.93 & Suffusion \\
\hline 29 & U-C5 & 97 & 100 & 29.4 & 34.5 & 12.5 & 0.02 & 0.0035 & 12.2 & 2.24 & Suffusion \\
\hline 30 & U-C10 & 98 & 100 & 28.2 & 37.5 & 13.5 & 0.02 & 0.0026 & 13.6 & 2.22 & Suffusion \\
\hline 31 & U-C20 & 99 & 100 & 26.3 & 41.7 & 15.1 & 0.01 & 0.0016 & 14 & 2.28 & Suffusion \\
\hline 32 & U-C30 & 99 & 100 & 24.7 & 43.3 & 15.7 & 0.01 & 0.0013 & 14.2 & 2.33 & Suffusion \\
\hline
\end{tabular}

Note: Here, ID, $i_{c r, a}, i_{c r, i j}, k_{i}$ and $k_{f}$ represent identifier, average critical hydraulic gradient, local critical hydraulic gradient, pre-test permeability and post-test permeability, respectively. 
Table 2. Summary of laboratory test data adopted from Israr et al. (2016) for validation of current model.

\begin{tabular}{|c|c|c|c|c|c|c|c|c|}
\hline \multirow{2}{*}{$\begin{array}{c}\text { Test } \\
\text { series } \\
\text { no. }\end{array}$} & \multirow{2}{*}{$\begin{array}{c}\text { Sample } \\
\text { ID }\end{array}$} & \multirow{2}{*}{$\begin{array}{l}\text { Loading } \\
\text { frequency, } \\
f(\mathrm{~Hz})\end{array}$} & \multicolumn{2}{|c|}{ Relative density (\%) } & \multirow[t]{2}{*}{$i_{c r, a}$} & \multirow[t]{2}{*}{$i_{c r, i j}$} & \multirow[t]{2}{*}{$i_{\Delta u}$} & \multirow{2}{*}{ Observation } \\
\hline & & & Pre-test & Post-test & & & & \\
\hline 1 & C & 0 & 95 & 95.2 & 50.2 & 52 & -- & Heave \\
\hline 2 & C & 0 & 95 & 95.3 & 51.4 & 55 & -- & Heave \\
\hline 3 & C & 5 & 96 & 100 & 49 & 56.7 & 4 & Heave \\
\hline 4 & $\mathrm{~F}$ & 0 & 97 & 97.4 & 44.5 & 41 & -- & Heave-Piping \\
\hline 5 & $\mathrm{~F}$ & 0 & 98 & 98.3 & 45.8 & 44 & -- & Heave-Piping \\
\hline 6 & $F$ & 5 & 97 & 100 & 42.4 & 46.5 & 7 & Heave-Piping \\
\hline 7 & G & 0 & 97 & 97.3 & 15.3 & 27.5 & -- & Suffusion \\
\hline 8 & G & 0 & 97 & 97.4 & 16.3 & 26 & -- & Suffusion \\
\hline 9 & $G$ & 5 & 97 & 100 & 12.8 & 30 & 9 & Suffusion \\
\hline 10 & $G$ & 10 & 98 & 100 & 11.8 & 30.4 & 10 & Suffusion \\
\hline 11 & $G$ & 15 & 97 & 100 & 11.5 & 30.3 & 10.5 & Suffusion \\
\hline 12 & $G$ & 20 & 97 & 100 & 11.2 & 31 & 11.5 & Suffusion \\
\hline
\end{tabular}


Table 3. Parameters for model validation.

\begin{tabular}{|c|c|c|c|c|c|c|}
\hline Test & & & & Model $\mathrm{k}$ & rameters & \\
\hline $\begin{array}{c}\text { Series } \\
\text { no. }\end{array}$ & ID & $f$ & $\left(\frac{k_{i}}{k_{f}}\right)$ & $\begin{array}{c}\text { A } \\
\text { (Eq. 7.9) }\end{array}$ & $\begin{array}{c}\text { B } \\
(\text { Eq. 7.10) }\end{array}$ & Reference \\
\hline 1 & S-C5 & 5 & 1.2 & 5 & 0.678 & \\
\hline 2 & S-C10 & 10 & 1.7 & 5 & 0.7105 & \\
\hline 3 & S-C20 & 20 & 2 & 5 & 0.73 & \\
\hline 4 & S-C30 & 30 & 2.4 & 5 & 0.756 & \\
\hline 5 & MS-C5 & 5 & 5.8 & 5 & 0.977 & \\
\hline 6 & $\mathrm{MS}-\mathrm{C} 10$ & 10 & 5.2 & 5 & 0.938 & \\
\hline 7 & MS-C10 & 20 & 5.5 & 5 & 0.9575 & \\
\hline 8 & MS-C30 & 30 & 6 & 5 & 0.99 & Current \\
\hline 9 & MU-C5 & 5 & 1.8 & 5 & 0.717 & study \\
\hline 10 & MU-C10 & 10 & 2.4 & 5 & 0.756 & \\
\hline 11 & MU-C20 & 20 & 2.5 & 5 & 0.7625 & \\
\hline 12 & MU-C30 & 30 & 2.7 & 5 & 0.7755 & \\
\hline 13 & U-C5 & 5 & 6 & 5 & 0.99 & \\
\hline 14 & U-C10 & 10 & 6.5 & 5 & 1.0225 & \\
\hline 15 & U-C20 & 20 & 7 & 5 & 1.055 & \\
\hline 16 & U-C30 & 30 & 8 & 5 & 1.12 & \\
\hline 17 & C & 5 & 1.1 & 5 & 0.795 & \\
\hline 18 & $F$ & 5 & 1.2 & 5 & 0.7885 & \\
\hline 19 & $\mathrm{G}$ & 5 & 2.2 & 5 & 0.8015 & Israr et al. \\
\hline 20 & $G$ & 10 & 2.4 & 5 & 0.808 & (2016) \\
\hline 21 & $\mathrm{G}$ & 15 & 2.6 & 5 & 0.6715 & \\
\hline 22 & $\mathrm{G}$ & 20 & 2.8 & 5 & 0.795 & \\
\hline
\end{tabular}

Note: Here, $f, k_{i}$ and $k_{f}$ represent cyclic loading frequency, pre-test permeability and post-test permeability, respectively. 